Florida International University FIU Digital Commons

FIU Electronic Theses and Dissertations

University Graduate School

$11-20-2001$

\title{
Francophone regionalism and its impact on west african integration
}

Sekou Camara

Florida International University

DOI: $10.25148 /$ etd.FI14052550

Follow this and additional works at: https://digitalcommons.fiu.edu/etd

Part of the African Studies Commons

\section{Recommended Citation}

Camara, Sekou, "Francophone regionalism and its impact on west african integration" (2001). FIU Electronic Theses and Dissertations. 1986.

https://digitalcommons.fiu.edu/etd/1986

This work is brought to you for free and open access by the University Graduate School at FIU Digital Commons. It has been accepted for inclusion in FIU Electronic Theses and Dissertations by an authorized administrator of FIU Digital Commons. For more information, please contact dcc@fiu.edu. 
FLORIDA INTERNATIONAL UNIVERSITY

Miami, Florida

FRANCOPHONE REGIONALISM AND ITS IMPACT

ON WEST AFRICAN INTEGRATION

A thesis submitted in partial fulfillment of the

requirements for the degree of

MASTER OF ARTS

in

INTERNATIONAL STUDIES

by

Sékou Camara

2001 
To: Dean Arthur W. Herriott

College of Arts and Sciences

This thesis, written by Sékou Camara, and entitled Francophone Regionalism and its Impact on West African Integration, having been approved in respect to style and intellectual content, is referred to you for judgment.

We have read this thesis and recommend that it be approved.

Framçois Debrix

Rod Neumann

John Clark, Major Professor

Date of Defense: November 20, 2000

The thesis of Sékou Camara is approved.

Dean Arthur W. Herriott

College of Arts and Serences

Interim Dean Sarpuel S. Shapiro

Division of Graduate Studies

Florida International University, 2001 


\author{
ABSTRACT OF THE THESIS \\ FRANCOPHONE REGIONALISM AND ITS IMPACT \\ ON WEST AFRICAN INTEGRATION \\ by \\ Sékou Camara \\ Florida International University, 2001 \\ Miami, Florida \\ Professor John Clark, Major Professor
}

French-speaking countries in West Africa have a long history of inter-state cooperation that goes to the French colonization of the region. The culmination of their integration resulted in the creation of L'Union Economique et Monétaire Ouest Africaine, UEMOA (The West African Economic and Monetary Union). With its financial and monetary arrangements, which include a common currency and a central bank, UEMOA is one of the most far-reaching examples of economic integration among developing countries. UEMOA's main advantage has thus been its "depth."

What makes the study of Francophone regionalism in West Africa even more interesting at this particular time is the fact that it is taking place within the context of a new wave of integration characterized by a trend towards broader regional integration in West Africa. The efforts towards broader integration in West Africa are reflected in the activities of the Economic Community of West African States (ECOWAS). 
ECOWAS has been able to engage in integration activities in a broad range of sectors. The existence of the two integration schemes has raised questions regarding the chances for the successful accomplishment of regional integration in West Africa. More specifically, UEMOA has been seen as posing an obstacle to the progress of the larger sub-regional grouping of ECOWAS. In this study, it is argued to the contrary, that UEMOA does not constitute an obstacle to ECOWAS.

The research demonstrates that UEMOA and ECOWAS complement each other in the process of West African integration. The concept of "depth" and "scope" of integration are introduced to illustrate the complementarity between the two West African integration schemes. UEMOA's depth is presented as a necessary complement to ECOWAS' scope. As a result, this analysis demonstrates that Francophone regionalism can indeed make a substantial contribution to West African integration. 


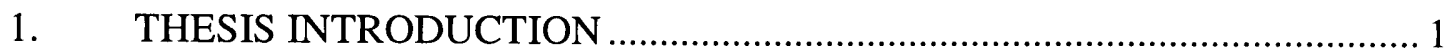

I. General Literature Review: Defining Integration ....................................... 3

II. Problematic and Methodology.................................................................. 10

III. Chapters Overview ............................................................................... 12

2. CHAPTER ONE: ORIGINS OF FRENCH-SPEAKING REGIONALISM

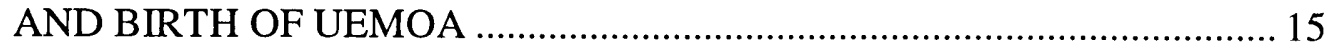

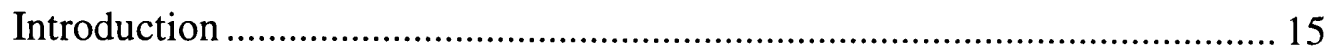

I. Colonial History of French West Africa ...................................................... 16

II. Post-Colonial Integration Efforts and Layers of Francophone

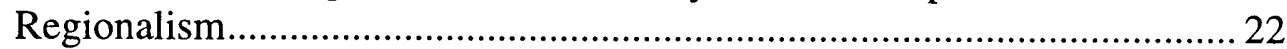

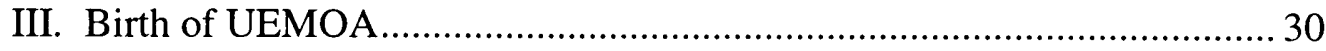

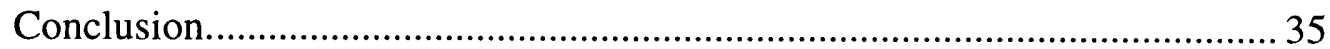

3. CHAPTER TWO: A TORTUOUS ROAD TO REGIONAL INTEGRATION: THE CREATION OF ECOWAS …........................................................... 41

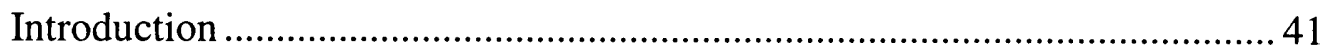

I. Motives for the Formation of ECOWAS .....................................................4 44

A. The Economic Rationale ............................................................ 44

B. The roles of Francophone States and Nigeria in the Formation of

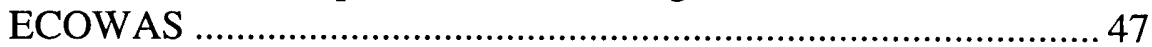

C. France and the Formation of ECOWAS .................................... 52

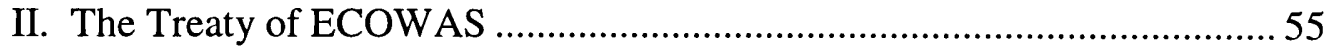

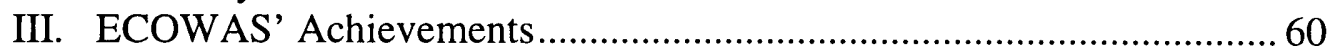

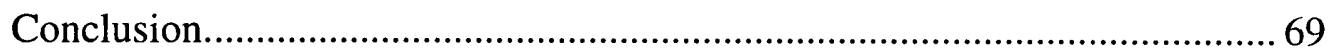

4. CHAPTER THREE: ECOWAS-UEMOA: CONFLICT OR

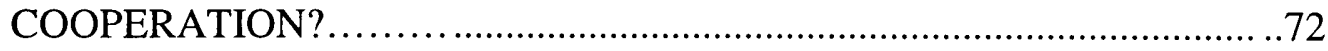

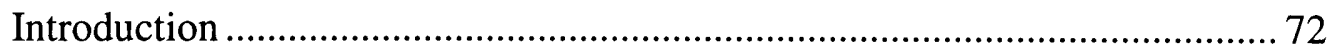

I. Potential for Conflict and Redundancy between ECOWAS and UEMOA 74

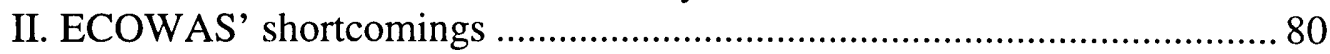

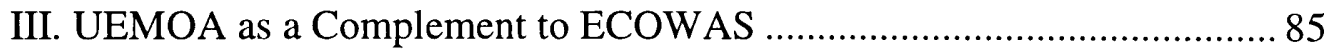

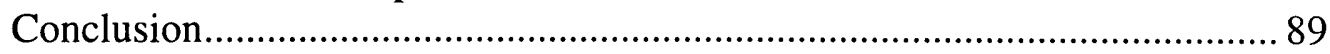

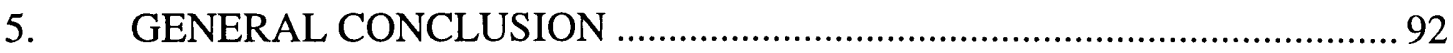

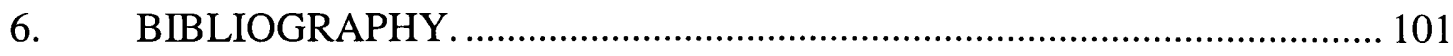




\section{THESIS INTRODUCTION}

The region defined as West Africa consists of sixteen nations sharing various colonial heritages including British, Portuguese, French and even American ${ }^{1}$. This makes West Africa the most culturally diverse region on the African continent, and certainly one of the most diverse in the Global South in terms of cultural heritage. In West Africa as in many places, linguistic affiliations have always constituted an important factor for regional alliances and cooperation. For this reason, West Africa provides a good setting for scholarship on geographical and linguistic regionalism.

In West Africa, linguistic regionalism has been mostly evidenced through Francophone countries' initiatives toward integration. This Francophone regionalism is even more interesting at this particular time because it is taking place within the context of revived activism toward broader geographical integration in West Africa. West African countries of all linguistic affiliations are stepping up their efforts to become economically integrated.

Such economists as Emeka (1990), Lavergne (1991), and Bach (1999), have noted, there has been a wide consensus on the need for West Africa's economies to become integrated in order to face collectively the challenges of globalization. In this regard, Lavergne remarks, regional or sub-regional integration is viewed as an imperative for African countries to achieve sustainable growth and development in the near future (1991:18). West African nations' integration efforts,

\footnotetext{
${ }^{1}$ Liberia was sometimes perceived as an American colony because of the pervasiveness of its relations with the US, and the deep American cultural influence
} 
therefore, deserve a closer analysis as the future welfare of these nations has been linked to their ability to become economically integrated. The strength of their integration initiatives as well as the nature of these processes, may provide us with a useful indication of the future development of these states.

Two institutions in West Africa that specifically symbolize these two parallel integration efforts among French speaking nations on the one side and all nations of the region on the other are respectively l'Union Economique et Monétaire de l'Afrique de l'Ouest, UEMOA (The West African Economic and Monetary Union), and the Economic Community of West African States (ECOWAS). These two institutions represent the most comprehensive integration schemes undertaken in this sub-region. The activities of UEMOA and ECOWAS therefore are very relevant to West Africa's integration efforts.

Since the term "integration" has been subject to various interpretations and definitions, it is important to first provide a general literature review of the topic. This will also provide us with a theoretical framework for the specific analysis of the integration movements in West Africa. The following section identifies different types of integration analyzed in the theoretical literature on integration. The methodology which is used to substantiate the argument of this research is presented in a subsequent section. This introductory chapter ends with an overview of all the chapters contained in this thesis. 


\section{GENERAL LITERATURE REVIEW: DEFINING INTEGRATION.}

In the economic literature, there appears to be no single definition of the term "integration". Rather, regional economic integration has been defined differently by various integration theorists. Essentially, two main approaches of the concept of integration are discernible from the literature dealing with the subject. According to a first approach, integration is defined strictly as a "process". Defined as a process, Diouf (1986:7) notes, economic integration includes all measures that aim at abolishing discrimination between economic units from different countries. Economic integration defined in this sense is seen as a process involving the combination of separate economies into larger economic units. Peter H. Smith (1993: 3), for instance, simply defines integration as a series of actions rather than a static condition or state of affairs. On the other hand, regional economic integration is rather defined by some theorists as a "state of affairs" or a "terminal condition" (meaning, end result) characterized by the absence of discrimination between countries. Keohane and Nye, for instance, have defined integration as "any level of association between actors" (Keohane and Nye,1975:366). John Pinder (1968:6) also uses this definition in his analysis of the European Economic Community. Ernst Haas uses the same approach when he defines regional integration as the terminal or resulting condition, or the outcome of regional cooperation activities (1970:44). Here, it is important to note that "regional cooperation," which is often used interchangeably with "regional integration," is given a slightly different meaning. Regional integration in this context helps describe the steps along the way toward regional integration (Haas, 1970: 34). 
Nonetheless, as Isebill Gruhn (1976:28) notes, regional integration, whether it is perceived as a process leading to the goal or as the goal itself, can still yield similar results. For this reason, an assessment of regional cooperation in West Africa will be an integral part of the analysis evaluating regional integration in that region. As cooperation generally refers to state relations, this research will thus not limit itself to an institutional analysis of ECOWAS and UEMOA. An analysis of the relations between the two schemes will then include an analysis of the relations between their respective member states. A definition of regional integration which does not fall exclusively in one of the categories described above is provided by Asante. Asante simply refers to integration as a situation which takes place when “ two or more countries in a particular area voluntarily join together to pursue common policies and objectives in matter of general economic development, or in a particular field of common interest to the mutual advantage of participating states" $(1986: 8)$.

The largest and most successful experiment of voluntary integration ever witnessed in the world was initiated in post World War II Western Europe. Western European integration initiatives sparked the beginning of what has been since referred to in the integration literature as the "first wave of regionalism". Many countries that were close neighbors and had common problems of economic development strived to establish some degree of economic cooperation. An important part of the integration theory is based on the analysis of this first wave of integration.

Some of the best known schemes in this first wave of regionalism extensively developed in the literature are the European Coal and Steal Community (ECSC 
established in 1951), the European Economic Community (EEC established in 1957), and the European Free Trade Association (EFTA established in1960) (Asante, 1997: 22). These post-war initiatives towards general cooperation and integration in Europe had a considerable impact on many other regions of the world. As a result, there was also a proliferation of regional economic schemes among developing countries (Diouf, 1977: 21).

This influence of the European model on developing countries explains why the literature on the "old regionalism" is not solely limited to Europe. This explains why in Latin America and Africa, for instance, free trade areas and custom unions mushroomed in the 1960s and early 1970s. The Latin America Free Trade Association (LAFTA) (1960), the Central American Common Market (CACM) (1961), the Central African Economic and Custom Union (1964), the Economic Community of West Africa (CEAO-Communauté Economique des Etats de l'Afrique de l'Ouest) (1973), and the Economic Community of West African States (ECOWAS) (1975) are some of the main schemes created in that first wave of regionalism in Africa and Latin America. In Asia, the Association of South East Asian State (ASEAN) (1968) also came in the first wave of regionalism.

Unfortunately, economic development through regional economic integration did not materialize among developing countries in that first wave of regionalism. Two decades after their establishment, virtually all these regional economic integration schemes among developing countries were judged by integration specialists as having failed or as being moribund (Asante, 1997:3). In spite of the high hope created by the first wave of regionalism, there is a consensus 
among theorists that the first round of integration among developing countries simply did not flourish. Not surprisingly, Diouf notes, by the late 1970 s enthusiasm for integration among developing countries was at its lowest (Diouf, 1977:122).

Nonetheless, by the late 1980 s, and early 1990 s a rediscovered enthusiasm for regional economic integration was once again evident in Asia, Africa, and in the Americas. Attempts to revitalize dormant regional groups or to form new blocs with a different approach to integration were suddenly on the increase. The formation of new powerful economic and trading blocs such as the European Union's Single Market (1992) and NAFTA (1993) seems to have fostered trends towards a new regionalism in the entire world economy (Asante, 1997:8).

This renewed trend marks what analysts have since referred to as the "second wave of regionalism" or the "new integration". In Latin America, it has been evidenced by the establishment of MERCOSUR in 1991. ECOWAS Revised Treaty of 1991, and the transformation of CEAO into UEMOA in 1994, are illustrations of this "new regionalism" in West Africa. Although trade remains an important element of the new regionalism, analysts have noted fundamental changes in the assessment of possibilities and limits of regional integration as opposed to the early concepts developed in the first wave of regionalism among developing countries (Asante, 1997:33-4).

A very central characteristic of the new regionalism is the multidimensional aspect of its implementation. As Louise Fawcett (1996) and Andrew Hurell (1996) note, the dividing line between political and economic regionalism has become ever 
harder to draw in the new regionalism. This is the case, both authors further note, because schemes formed under the new regionalism approach have been concerned with political , economic, and security issues at the same time. As Fawcett states in the introductory chapter of her book, "the factors that underpin and sustain such projects are often far from solely economic, and economic regionalism may carry with it important geopolitical and security consequences" (1996:4).

Unlike the old regionalism, economic integration under the new regionalism is not solely built around economic considerations. Although there were security issues at the beginning of the European integration right after World War II, these issues were not tackled directly and integrated in the process of integration at the time. This was the case because the functionalist approach behind the first wave of regionalism prevented these kind of issues from being considered. As Diouf (1977: 35) notes, European integration was constructed around the notion of trade liberalization before expanding to other issues. European integration became multidimensional over time but only through the "spillover" effects of economic liberalization posited by the functionalist approach. In the new regionalism, due to the specific context of many developing countries, issues of political security cannot not be considered separately from regional economic issues. Consequently, issues of political security had to be fully incorporated into the broad framework of regional economic integration in the new regionalist perspective. This allow us to understand why ECOWAS' interest in regional peacekeeping activities has been a recurrent subject in the analysis of the process of West African integration (Smith, 1993:156). 
Bjorn Hettne defines the new regionalism as a "multidimensional process of regional integration which includes economic, political, social and cultural aspects" (1995:13). As Fawcett and Hurell accurately remark, this is an important departure from the European model which tended to focus resolutely on the specific question of economic integration (1996:4). In the new regionalist approach, convergence toward other non-economic issues is seen as a quintessential means to reinforce the overall process of regional integration. Hettne's definition also brings us back to the differentiation between integration as a "process" and integration as a "state of affairs". It clearly transpires from Hettne's, Fawcett's and Hurrell's definitions that the new integration emphasizes integration as a process. Thus, whenever one talks about new regionalism, in the new tradition one implicitly refers to integration as a "process" rather than as a "state of affairs". In fact, not surprisingly, most analyses of integration as a "state of affairs", such as those made by John Pinder and Ersnt Haas, were made at the time of the first wave of regionalism.

Even in its economic approach to integration, the new regionalism in developing countries departs fundamentally from the old regionalism of the 1960s and 1970s. The economic application of the old regionalism represented an extension from the national to the regional level of the import-substitution industrialization (ISI) strategy developed by Raul Prebisch and the Economic Commission for Latin America (ECLA) (Bach, 1999:17). ISI was enthusiastically adopted at regional levels by developing countries anxious to obtain preferential agreements and protect their infant industries against competition from the international system. But these strategies of withdrawal from the international economic system failed at both 
the national and regional levels as rapidly declining growth rates and loss of competitiveness in industrial structures increasingly cut off developing countries from foreign technology (Bach, 1999:17-19).

The failure of ISI in much of the developing world, in contrast to the success of the outward-oriented policies of East Asia, for example, led to a general shift among developing countries towards favoring rather than discriminating against exports (Fawcett, 1996:94). By contrast, the second wave of regionalism is outward-looking. It is taking place in a context of globalization precisely characterized by outward looking policies. As ISI policies have been abandoned at national levels, they have also been replaced by others policies at regional levels.

Furthermore, whereas in the old regionalism developing countries pursued integration exclusively among one another, in the new regionalism developing countries are seeking more partnership with developed countries. Although a strengthening of South-South economic relations is still sought under the new regionalism, an interruption or reduction of North-South economic relations is no longer posited. As Bach simply states, "the second generation regionalism pursues a strategy of economic reintegration" (1999:19). Retrospectively, we can see that the new regionalism, with its liberal policy focus, was partly stimulated by pressure from the World Bank and the International Monetary Fund. 


\section{PROBLEMATIC AND METHODOLOGY}

The existence of the two integration schemes has raised questions regarding the chances for successfully accomplishing regional integration in West Africa. The possible incompatibility of the two integration schemes has been essentially a subject of debates because of the perception of linguistic regionalism as being inherently detrimental to broader sub-regional integration. Specifically in terms of West Africa, it has been asked whether Francophone regionalism as embodied by UEMOA poses an obstacle to the progress of the larger sub-regional grouping of ECOWAS $^{2}$

This research has two principal aims:

* To document the history of West Africa's integration through the separate experiences of UEMOA and ECOWAS in order to understand the dynamics of linguistic regionalism and geographic regionalism in the context of both the old and the new regionalist theories.

* To evaluate the prospect of full-scale integration in West Africa, given the current co-existence of the two organizations.

In achieving these principal aims, the research will answer specifically the following questions:

1) Can West African integration work in the current context of new regionalism?

2) Can it work with both ECOWAS and UEMOA as integral parts of the integration scheme?

\footnotetext{
${ }^{2}$ Most analysts supporting ECOWAS such as Jules Emeka, A. S. K. Asante and Amad Aly have at least asked that question in their assessment of the capabilities of the regional organization.
} 
3) In this perspective, can UEMOA actually reinforce ECOWAS?

4) Can the linguistic bond among Francophone states facilitate the larger process of integration in the sub-region?

This thesis will answer these questions affirmatively. It will argue that West African integration can work, that it can function with both ECOWAS and UEMOA. Because UEMOA can indeed support the efforts of ECOWAS, the linguistic bond among Francophone states is not to be perceived as an obstacle to the new regionalism in West Africa. Ultimately, I want to argue that French speaking regionalism can contribute to West Africa's overall integration, and that UEMOA and ECOWAS can complement each other.

The concepts of "scope" and "depth" of integration will be mobilized to illustrate the complementarity between the two West African integration schemes. Peter Smith (1993: 5-7) has introduced the concepts of "depth" and "scope" as variables for evaluating regional integration schemes in his analysis of European integration. "Scope" refers to the range and variety of issue-areas and transactions falling under the purview of the integration scheme. "Depth" refers to the degree of development and complexity of policy coordination or harmonization.

While UEMOA brings depth to West Africa's integration, ECOWAS in turn has a scope of cooperation among its members that UEMOA lacks. Meanwhile, to move further, ECOWAS' integration requires depth. Thus, cooperation with UEMOA can bring to ECOWAS both the depth and the scope it is searching for. By merging their institutional structures, ECOWAS and UEMOA can operate as a full integration system. An emphasis on both depth and scope also helps re-contextualize 
West African integration within the broader theoretical framework of the new regionalism. Thus, my analysis of ECOWAS and UEMOA and their current integration efforts will contribute to the literature on the new integration movements.

\section{CHAPTERS OVERVIEW.}

The first chapter reviews the history of French-speaking regionalism in West Africa, providing some background information on integration efforts in this region. The chapter begins by examining the historical context (both political and economic) that led to the formation of UEMOA. This historical context allows us to see how Francophone regionalism moved from the "old regionalism" to the "new regionalist" scheme. The establishment of UEMOA as a result of successive evolutions and attempts of integration among Francophone West African countries is presented as a manifestation of the "new regionalism" in French speaking West Africa.

A subsequent part of this chapter is devoted to a discussion of UEMOA's objectives and current achievements. These objectives and achievements are presented within the broad framework of integration schemes formed in the context of the new regionalism. An analysis of Francophone states' monetary integration efforts will serve to illustrate the "depth" of these countries' integration.

The second chapter starts as a historical analysis of the formation of ECOWAS as the first comprehensive integration scheme in West Africa. This 
chapter presents the economic rationale behind the formation of ECOWAS' integration scheme. The role of some key players in the establishment of this integration scheme is crucial. This chapter also traces the transformation of ECOWAS from a first wave integration scheme to a new regionalist model. In this context, I discuss ECOWAS' objectives and present its projects and achievements in relations to those goals. The chapter highlights the multidimensional aspects of ECOWAS in order to show the "scope" of its model of integration. Understanding this conceptual aspect of ECOWAS is critical in assessing the level of complementarity between ECOWAS and UEMOA.

The third chapter presents several arguments made against the idea of compatibility of the two organizations in the sub-region. These arguments, as will be seen, are essentially cases made against UEMOA, which is perceived as inhibiting ECOWAS' efforts toward greater regional integration. Two specific approaches in assessing the incompatibility of the two schemes are presented. As UEMOA has been held responsible for ECOWAS' disappointing results, an analysis of ECOWAS' shortcomings allows us to assess the actual share of responsibility of the Francophone states for these shortcomings.

Following this assessment, which shows that UEMOA is not responsible for ECOWAS' shortcomings, the chapter evaluates how UEMOA can in fact contribute to ECOWAS' objective of fully integrating the West African region. The area of monetary integration is specifically studied, since it offers a good case study of the complementarity between UEMOA and ECOWAS. 
In conclusion, it will appear that cooperation between UEMOA and ECOWAS is an imperative choice for the successful completion of regional integration in West Africa. The research will clearly demonstrate that UEMOA and ECOWAS are in fact necessary complement to each other in the current context of integration under the new regionalism. Both organizations could be seen as integral parts of a multidimensional process of regional integration in West Africa. 


\section{CHAPTER 1. ORIGINS OF FRENCH-SPEAKING REGIONALISM AND BIRTH OF UEMOA.}

\section{INTRODUCTION.}

Francophone regional organizations are among the oldest and most deeply rooted in Africa and the developing world in general. To trace the origins of French-speaking regionalism in West Africa one has to go back to the French colonization of the region. More importantly, one has to understand the impact of the French style of colonization on the subsequent formation of regional organizations in Francophone West Africa after the independence. For this reason, this chapter will start with a review of some aspects of French colonization in West Africa.

Subsequently, the chapter will discuss the most important post colonial integration initiatives among Francophone West African states. This will allow us to see the different motivations and objectives behind each of Francophone integration scheme in the sub-region. In this historical analysis, the passage from the first wave of regionalism to the new wave of integration will be particularly noted. Leading to this analysis will be the discussion on the establishment of UEMOA as an integration scheme in the new wave of regionalism. UEMOA's objectives will be presented and placed within the context of the new regionalist movement. Its achievements will also be discussed with a particular emphasis on the areas where its integration has reached more depth. This will allow us to illustrate in a subsequent 
chapter how UEMOA could most contribute to West Africa's integration by serving as a complement to ECOWAS.

\section{COLONIAL HISTORY OF FRENCH WEST AFRICA.}

In contrast to the British, the French used a form of direct rule in their colonization of Sub-Saharan Africa. This colonial style was characterized by the centralization of the administrative process that resulted in the formation of two colonial entities: L'Afrique Occidentale Française (AOF) (French West Africa) and L'Afrique Equatoriale Française (AEF) (French Equatorial Africa). AEF and AOF functioned in essence as two federal states with their respective capitals in Dakar, Senegal and Brazzaville, Congo.

During colonial times, all Francophone West African nations shared common membership in AOF. That common membership in AOF resulted in the sharing of a number of vital institutions put in place to facilitate the centralization of the French administrative rule. The Comptoire Franco-Africain (CFA), which was established in 1907 to replace the French Franc as the new colonial currency, was one of the institutions shared by all AOF states (Aly, 1994:10-11). The currency became known as the CFA Franc. The new financial entity was incorporated into the French monetary system through the Banque de l'Afrique Occidentale (BAO), which was created by the French colonial authorities in 1901 to serve as an issuing institution for all colonies of Central and West Africa (Aly, 1994:11).

Furthermore, it is relevant to note an important characteristic of the AOF federation that helps to explain the "natural inclination" of Francophone West 
African countries to stay grouped. Namely, AOF, as a federal state, was a contiguous geographic entity. Unlike the Anglophone colonies, all Francophone territories in West Africa were linked in a way they could form collectively a single geographic unit. Today the Anglophone states of Ghana, Nigeria, Sierra Leone and Gambia have no common borders, while the Francophone states are all geographically connected to each other. In fact, it is possible from any Francophone state of West Africa to join any other Francophone state of the region by land without having to cross a non-Francophone state.

The contiguity among French-speaking countries facilitated the process of physical integration during colonization. As a result, when French West African colonies became independent, many of them also shared in common a number of physical infrastructures (i.e., highways, railroads, schools) in addition to financial and social services. Thus, there was an additional rationale beyond the simple linguistic bond for former French colonies of West Africa to stay integrated after independence. Cote d'Ivoire, for instance, heavily depended on the migrant workers from Burkina Faso to supply the labor in its plantation economy. On the other hand, Burkina Faso, which is a landlocked country, saw the railroad from the Ivorian coastal city of Abidjan to its capital (Ouagadougou) as its main link to the world economy. Similarly, the railroad between Dakar, Senegal, and Bamako, Mali also provided the latter country with a window to the rest of the world. The same type of relation also existed between Togo and Benin on one side, and Niger on the other (Rapley, 1990:33). Interestingly, most scholars examining Francophone regionalism have failed to recognize this economic rationale behind 
the formation of French-speaking regional organizations, focusing instead on the linguistic bond, or on the links with France. Even prominent analysts of Francophone regionalism such as Lavergne, Bach, and Emeka omitted taking into account this economic rationale behind Francophone regionalism.

When explaining the reasons behind the advent of Francophone regionalism in West Africa, the structure of the French colonial economy is simply too often overlooked. John Rapley (1990) provides us with very useful clues for understanding Francophone states' strong desire for regional integration among themselves. As Rapley explains, the entity of French West Africa, as a classical colonial economy, was essentially subordinated to France's needs. It was to supply primary goods and raw materials for the metropole and provide export market for French manufacturers (Rapley,1990:16).

In order to achieve this goal, the French organized the colonial economy in a very specific manner to take into account the differences in resource endowment and land fertility among AOF territories. The colonies were thus divided in two distinct groups. The first group of colonies were the suppliers of cash crops for French markets. Coastal colonies such as Côte d'Ivoire, Guinea, Senegal and Togo were all in this first group. In these territories, French colonial authorities encouraged the expansion of plantations, specifically targeting coffee and cocoa, palm oil, and bananas. Because of their vitality to the French colonial economy, those coastal regions also received the bulk of French colonial investments in infrastructure and social services. In essence, as Rapley notes, those are the regions that benefited most from French colonialism. The French placed a particular emphasis on 
developing these coastal regions where transportation cost was low, and soil and climate were best suited for producing export crops (Rapley,1990:17-19).

The second group of colonies were classified as the labor reserves and food suppliers for the cash crop producing colonies. The colonies in this group were composed of the landlocked territories of Mali, Burkina Faso, and Niger. In the words of G.B. Kay, "the colonies in this second group greatly suffered from under exploitation relative to their neighbors of the first group" (1990:5). As Rapley explains, the inland colonies, which were only suited for food production, were neglected by France because they could satisfy they own food needs. As a result, the colonial economy scarcely extended its transportation networks and production infrastructure into those territories.

In fact, in the late 1930s, when the colonial administration finally extended railways and paved roads into the inland territories, it was specifically with a view to benefiting the southern mines, plantations, forests and concessions which needed to recruit labor and buy food to feed their laborers (Kay, 1990:17). In this process, the inland territories not only were losing their best workers, but the revenue they were earning from the sale of food and crops to the neighboring countries was also eclipsed by the revenues the latter territories were making from the sale of export crops and minerals. In effect, as it appears, the inland territories subsidized the development of coastal territories by providing them with cheap labor and food.

As this situation lasted throughout the colonial era, it had a profound impact on intra-Francophone state relations at the time of independence. Because of the presumption placed on the lack of complementarity among developing countries' 
economies as they often have similar patterns of production, the interdependence of some Francophone West African countries' economies has often been overlooked. By 1956, for instance, Cote d'Ivoire was already employing 300,000 migrant workers from Upper Volta (now Burkina Faso) (Rapley, 1990:18). As the number of migrant workers kept increasing, so was the general level of interdependence between inland colonies and coastal territories. Workers' remittance from coastal colonies thus became an important source of revenue for inland colonies such as Upper Volta, French Sudan (Mali), Niger, and also Chad (Rapley, 1990:19).

Hence, at the time of independence, there was a very clear economic rationale for the former French colonies of West Africa to maintain intact at least some of the links they developed throughout colonization. It is thus not a surprise that the only country that chose not to participate in any form of regional alliance based on the preservation of these colonial legacies was Guinea. Guinea, which opted out of the French Union, was also the most self-sufficient in the entire AOF federation in terms of resource endowment, food production and labor supply. So, Guinea's withdrawal from the collective institutions of Francophone regionalism did not initially affect it adversely, as it would have immediately affected other former coastal colonies such as Côte d'Ivoire and Togo. It is thus understandable that former French colonies in West Africa not only chose to maintain their links, but also sought to further reinforce them. These efforts constituted a key element in their development strategies. Francophone countries of West Africa simply did not underestimate their mutual inter-independence. This contrasted with the approach of Anglophone countries of West Africa which systematically dismantled the few 
existing collective institutions put in place by the British during colonization (Asante, 1997: 35-36).

Today, it is ironic, as Asante notes, that it was at the insistence of Kwame N'krumah, the champion of Panafricanism, that Anglophone states of West Africa disbanded the few joint institutions that they inherited from British colonization (Asante, 1997: 36). Consistent with the political ideology of anti-imperialism, N'krumah perceived the maintenance of institutions inherited from colonization and still appended to the former colonial power as favoring imperialism and neocolonialism. As a result, joint Anglophone institutions such as the British West African Currency Board, the West African Cocoa Research Institute and the West African Airways Corporation were all dissolved, advancing in the process what Asante refers to as the "balkanization" of Anglophone West Africa (Asante, 1997:36). This "balkanization" of Anglophone West Africa was exacerbated by the fact that the British themselves had manifested little direct interest in maintaining their support of those institutions, or any new ones (Mazrui, 1977: 22).

As Emeka (1990:53) also notes, this contrasted remarkably with the French approach as a number of agreements signed between France and the former colonies just before independence or soon after supported the continuation of numerous forms of cooperation and integration arrangements among Francophone states. Among these integration arrangements that were maintained through cooperation agreements with France were the African Association of Postal Services (L'Union Africaine et Malgache de Postes et Telecommunications) UAMPT, the West African Monetary Union (L'Union Monetaire Ouest Africaine) UMOA, the Central Bank of 
West African States (La Banque Centrale des Etats de l'Afrique de l'Ouest)

BCEAO, and most notably the CFA Franc, which became Communauté

Financière Africaine (African Financial Community) after the independence (Emeka, 1990:53) .

\section{POST COLONIAL INTEGRATION EFFORTS AND LAYERS OF FRANCOPHONE REGIONALISM.}

Active French support for Francophone integration schemes aided by Francophone states willingness to stay grouped led to the consolidation of existing integration schemes and the formation of new ones after the independence. The oldest of these schemes was Le Conseil de l'Entente, established in 1959 when all colonies were already under self-rule and only a few months before formal proclamation of independence. The Conseil de l'Entente, which was initiated by Ivorian president Felix Houphouet- Boigny, was initially designed to undermine the establishment of the short-lived Mali Federation uniting Senegal and the French Sudan (now Mali).

The Mali Federation was a strong political union between those two states, and its founders envisioned that it would be extended to the other nations of the region. Because the Mali Federation reflected the growing regional influence of Senegal's President Léopold Sédar Senghor, Houphouet-Boigny, who felt overshadowed and resented strong political unions between African states, mounted his own scheme by attracting all potential new members of the Mali Federation. The 
Conseil de l'Entente was thus established as a looser form of political union among Côte d'Ivoire, Burkina Faso, Niger, Benin and Togo, all of which were approached at one point or another to join the Mali Federation. France's strong backing of the Ivorian president had a great impact on the decision of those states to join his organization rather than the Mali Federation (Bach, 1990:45). As Bach reveals, the Council became a major instrument for Ivorian regional diplomacy as it helped to isolate rival poles of influence such as Senegal and Guinea in the Francophone family, while creating a front against potentially dominant Anglophone nations such as Ghana and Nigeria.

With French support, the Council created the Fonds de Solidarité (solidarity funds) which carried out limited redistribution of the coastal states' customs and excise revenues to landlocked countries. In essence this gave coastal countries, notably Côte d'Ivoire, the assurance of continued access to cheap labor from landlocked countries. In 1966, the Council created the Fonds d'Entraide et de Garantie des Emprunts to promote economic cooperation among member states by stimulating the flow of foreign private and public capital toward poorer members. The Council, though it never had any significant ambitious political objective, nonetheless had an impact on its members, especially on the poorer ones, because of the amount of external aid and support it was able to get in the West, and especially from France. Nevertheless, the Council would lose much of its political significance when all member states would find themselves in a larger and more substantive Francophone organization. 
In 1973, political considerations led the four Council members, plus Senegal and Mali, to revitalize one of their old schemes by expanding its activities. All of them were at that time members of UDEAO (l'Union Douaniere et Economique de l'Afrique de l'Ouest). UDEAO was a Francophone custom union put in place during self-rule under French colonization, but it lacked vigor as none of its members made serious efforts to implement its provisions. This led to the signing of the Treaty of Abidjan on April 17, 1973, which marked the birth of the West African Economic Community (CEAO-Communauté Economique de l'Afrique de l'Ouest).

As Bach noted, the CEAO Treaty represented the most elaborate prospect for Francophone economic cooperation in West Africa up to that date (1990:57). Essentially, it reconciled the split created by the Conseil de l'Entente, and the Mali Federation, as all Francophone states of West Africa (with the usual exception of Guinea) joined the new organization. As the Conseil de L'Entente and the Mali Federation were created for political reasons, CEAO was the first postcolonial integration scheme among Francophone West African states whose creation was economically motivated. CEAO became the largest grouping of Francophone states in West Africa since AOF.

The creation of CEAO came in the specific context of the first wave of regionalism among developing countries. European progress toward general cooperation and integration in the post-war decades is what sparked that first wave of regionalism among developing countries. In that first wave of integration, many developing countries that were close neighbors and had common problems of 
economic development began to seek some degree of economic cooperation among themselves (McCormick, 1999:12). The geographical aspect was indeed noted by other integration theorists such as Peter Smith (1993) and Louise Fawcett (1996) as an important factor in the formation of first wave integration schemes. In West Africa, Francophone states that had always felt close to each other, and were indeed geographically connected, also had common problems vis-à-vis economic development. The absence of geographical links certainly explains why, on the other hand, there was no attempt at regional integration among Anglophone West African countries during the first wave of integration.

The leaders of Cote d'Ivoire and Senegal simply found it imperative to bury their rivalry for leadership in the Francophone family, and to instead establish a regional Francophone grouping capable of acting as a counterweight to Nigeria's growing regional influence (Lavergne, 1991:86). As Asante (1986) notes, CEAO was established in an era characterized by the inability of Anglophone and Francophone West African countries to break out of their colonial heritages and become closer to each other. Up to that date, he recalls, attempts made by Anglophone and Francophone countries toward the establishment of regional organizations had simply proven to be less fruitful than efforts made by Francophone countries among themselves. For this reason, it did not come as a surprise that CEAO became an archetype of a well-elaborated regional cooperation scheme in that first wave of regionalism in Africa (Lavergne, 1986:89).

On the economic front, Cote d'Ivoire and Senegal expected the CEAO Treaty to provide their national industries with an opportunity to first adapt to the 
35 million strong Francophone market, before being able to compete on a wider West African market dominated by Nigeria. Industrial ventures established in the two countries were expected to realize the economy of scale necessary to compete with Nigerian manufactured products (Emeka, 1990: 57).

The major objectives of CEAO were, first, to improve the infrastructures of the area as a whole through cooperation in the development of transportation and communication; second, to promote and accelerate the collective industrialization of member states; and third, to facilitate trade among members in both manufactured products and raw materials (Asante, 1986: 48). In addition, as a general objective, the treaty aimed at the consolidation of joint policies and measures in other sectors of economic activities.

The implementation of the treaty began in early 1976 , and within two years its projected mechanisms were fully in operation. Among the early achievements of the CEAO was the introduction of the Taxe de Cooperation Regionale (TCR). This tax collected duties that were previously levied by individual states on manufactured import from members of the communities. In order to favor the poorer countries, different tax rates were applied to similar goods produced by more than one country within the community (Emeka, 1990:57-58). The establishment of the TCR was meant to be the first step toward the total abolition of internal customs barriers and the adoption of a common external tariff. Based on some analyses, the TCR has been more beneficial to exports from Cote d'Ivoire and Senegal as these were CEAO's most industrialized nations (Lavergne,1991:85). To compensate for the presumed loss of revenue for poorer member states, however, 
a Community Development Fund (FDC) was established to allocate two-thirds of its resources as direct compensation for reduced fiscal revenue. The remaining third was designed to be used for regional studies and projects in favor of the less developed member states. This mechanism permitted a smooth functioning of the organization (Emeka, 1990:58).

Without a common financial basis, Bach (1990:56) remarks, these early advances of CEAO would have certainly been made considerably more difficult. In fact, at the establishment of the CEAO, the founders relied as a source of optimism for the new organization on the fact that all members states already shared a common financial basis provided by two institutions that would become the pillars of CEAO. One of these institutions is La Banque Centrale des Etats de l'Afrique de l'Ouest (BCEAO- Central Bank of West African States). The BCEAO was created after the Banque de l'Afrique Occidentale (BAO-Banque of West Africa), which existed during colonization, was divided before independence in two separate institutions: the Bank for Central African States (BEAC), and the BCEAO for West African states. The BCEAO was established as the issuing authority for the regional union's common currency, the CFA Franc.

An important feature of the BCEAO is what Mendhora (1997:18) recognizes as its relatively high level of independence. In fact, as Mendhora reveals, the BCEAO ranks slightly above average in its independence for OECD central banks and well above the average for developing countries. Its political and economic independence issues from its freedom from pressure from any single fiscal authority and the statutory limits on government borrowings. Borrowing by member states to 
the central bank is limited to $20 \%$ of the government's previous year fiscal receipts. This has resulted in a lower rate of inflation among CEAO countries compared to other countries of the continent (Lavergne, 1997:122). Its performance has conferred on the BCEAO an enviable degree of credibility rarely enjoyed by developing countries' financial institutions.

BCEAO's successes have been possible mainly because of the supranationality it acquired from its regulatory body, the West African Monetary Union (UMOA-Union Monetaire Ouest Africaine). UMOA has been seen as the most significant institution of Francophone regionalism because it provides a financial backbone to the integration scheme (Bach, 1990:18). As Peter Smith (1993) might also characterize it, it brings "depth" to the integration. The scheme has depth because it is a very sophisticated and complex arrangement. Its achievement reflects an advanced level of integration. As an institution inherited from colonization, UMOA was reformed several times after independence to give the institution more autonomy vis-à-vis France. Nonetheless, the link with France remained strong, and in many ways, the nature of that union with France constituted the most distinctive feature of the union.

The union was characterized by the pegging of its member's common currency, the CFA Franc to the French Franc at a fixed rate. This guaranteed the UMOA states free convertibility between their currency and the French Franc (and thus all other freely exchanged currencies). As a result, unlike other African or third world countries' currencies, the CFA Franc was not undermined by black market exchange rates. On the downside for UMOA member states, surrendering their 
monetary sovereignty to a regional central bank (i.e., BCEAO) meant that they could not compel the institution to fund activities that they deemed essential to their own development (Bach, 1990:67). Nonetheless, the benefit of this monetary orthodoxy, which is the guarantee provided by the French treasury, has seemed to outweigh the negative effects of the restrictions created by the arrangements.

Thus, in the area of monetary integration, Francophone West African states have made more concrete accomplishments than almost any other integration scheme among developing nations. Because of their monetary and financial arrangements, Francophone African integration schemes are characterized by their depth. The depth of Francophone integration schemes comes from the extent of their policy coordination and harmonization in the monetary area (Smith, 1993:34). Mendhora, for this reason, even described UMOA's arrangement as one of the world most far-reaching examples of monetary integration. In his words, UMOA represents a "complete monetary union in the sense that its members share a fully convertible common currency issued by a supra- national central bank that oversees the operations of an internal reserve pool" (1997:56). Yet, as Bach notes, if UMOA has been a successful monetary integration scheme, it has been nothing more than that . This is to say that very little was actually accomplished in the sense of full economic integration outside the monetary area and regional trade preference. The UMOA/ CEAO scheme has simply not resulted in greater harmonization in macroeconomic policy among member states. This need for more extensive economic harmonization is what ultimately led Francophone West African leaders to reshuffle the entire organizational structures of their integration scheme. CEAO, 
which was born in the first wave of regionalism out the desire of Francophone states to challenge Nigeria, finally needed major restructuring to become an efficient tool of economic integration among French-speaking countries (Bach, 1997:61).

\section{BIRTH OF UEMOA}

In 1994, Francophone leaders of West Africa decided to undertake an ambitious integration project capable of turning their monetary union into a strong economic union with a single market (Bach, 1997:63). Thus, in January of that year, Francophone West African states signed a new treaty expanding their monetary integration arrangements into a new economic and monetary union (UEMOA). This same treaty put an end to the CEAO institution, as all its provisions were essentially merged into the new institution. This initiative reflected the apparent realization of the need to match the existing monetary union with further economic integration. Philosophically, UEMOA also broke with the competitive approach of CEAO, as it conceived its goals within the broader context of West African integration as highlighted in the ECOWAS Treaty (Asante, 1997 67).

The competitive nature of Francophone regionalism against Anglophone Africa officially ended with the suppression of CEAO. The suppression of CEAO and the establishment of UEMOA also came in the context of the new wave of regionalism which had reached Africa. CEAO, like most other economic integration schemes among developing countries in the first round of regionalism, 
had proven ineffective because of its inability to promote economic development (Daddieh, 1997:78).

As in other regions reached by the new wave of regionalism, motivations to revitalize dormant blocs or to form new ones with a different approach to integration became apparent in Francophone West Africa. For this reason, the UEMOA Treaty underlines the harmonization of macroeconomic policies as one of its priorities. This was never seriously attempted in the defunct scheme (Lavergne, 1997: 122). The emphasis on macroeconomic policy coordination illustrates a fundamental difference with the limited focus on regional trade preferences that also characterized first wave integration schemes (Daddieh, 1997:23).

UEMOA's main objectives as underlined in its treaty are:

1) To reinforce the competitiveness of the economic and financial activities of member states in the context of an open and rival West African market, and a rationalized and harmonized judicial environment.

2) To ensure the convergence of macro-economic performances and policies of member states through the institution of a multilateral control procedure.

3) To create a common market among member states based on the free circulation of people, goods, services, capital, and on the right of people exercising an independent or remunerated activity, to establish common external tariffs as well as common commercial policies.

4) To coordinate national sector-based policies with the implementation of common actions and conceivably common policies in the following domains: 
community-based land reclamation, agriculture, environment, transport, infrastructure, telecommunications, energy, industries and mines.

5) To harmonize the legislation of member states for the proper functioning of the common market if the need to do so arose .

All these objectives of UEMOA are stipulated in its treaty as objectives to be achieved within the broader framework of West Africa's regional integration as conceived by ECOWAS (UEMOA Official Journal, August 2000). Thus, an important distinction between CEAO and UEMOA is the fact that UEMOA does not conceive of its role in isolation from ECOWAS. Furthermore, the wide range of objectives included in UEMOA's treaty highlights another important distinction with CEAO. UEMOA has included in its objectives cooperation in other sectors of activities such as agriculture, transport, and telecommunication. These sectors of activities were never part of CEAO's immediate objectives. Thus, a fundamental distinction between the old and the new Francophone schemes is the multidimensional approach in implementing integration. The multidimensional approach to integration is noted by Louise Fawcett (1996) and Andrew Hurell (1996) as one of the distinctive features of second wave integration schemes. As in most first wave integration schemes, CEAO's integration activities were limited to only a few economic sectors (trade liberalization for example). Just as in the early European model posited by the functionalist approach, the scope of integration was supposed to become wider overtime through "spillover effects" (Diouf, 1977:36).

Of all the regional integration schemes in Africa, Lavergne (1997:118) remarks, UEMOA is the one that incorporates the strongest measures of 
supranationality. This is not only manifested in UEMOA's objectives of policy harmonization, which are more far-reaching than other regional integration schemes, but also in its organizational structures. In fact, UEMOA's institutional organization seems to have been modeled after the EU (Bach, 1999:54). As in the latter institution, the two supreme organs of UEMOA are the Conference of Heads of States and the Council of Ministers, whose prerogatives are very similar in both institutions. In addition, the UEMOA treaty also established a Commission, and a Court of Justice. It even provides for the creation of a Regional Parliament whose members would be directly elected in their home countries. As an intermediary step, an Interparliamentary Committee was put in place with members coming from national parliaments (UEMOA, Official Journal, August 2000).

As most analysts agree, UEMOA's potential is remarkable, and by all accounts, the level of performance has been above that of any other African scheme (Bach, 1999:167). Since its creation, UEMOA has taken steps to further deepen the monetary integration. One of the most significant achievements since the transformation of UMOA into UEMOA has been the creation of a regional stock market, La Bourse Regionale des Valeurs Mobilieres (BRVM). Located in Abidjan, Côte d'Ivoire, the BRVM has a local branch in each one of the member states of UEMOA. One of the objectives of this stock market has been to bring together buyers and sellers from across the union. Through this process, it contributes to the dissemination of information as well as the organization of the regional financial market. Since January 1998, when it started, the BRVM has 
brought members of the business community of UEMOA states into closer contact (UEMOA Official Journal, January 2000).

Also contributing to the deepening of monetary integration within UEMOA is the harmonization of the accounting systems through the adoption of a West African Accounting System (Systeme Comptable West Africain, SYSCOA) which set common norms and regulations. Similarly, a Common Investment Code, (Code Communautaires des Investissements) was established to provide foreign and local investors with an adequate and uniform legal framework for investments inside the community. Harmonization of various national judicial systems in the monetary and financial sectors was also undertaken to accomplish the institution's goal of complete convergence within the community. Resolutions have already been passed aiming to harmonize national tax laws across the community (UEMOA Official Journal, February 2000).

As part of its objective to create a strong local competitive market, UEMOA has also adopted a common industrial policy to affirm member states' refusal to stay marginalized in the ongoing process of globalization. The adoption of that policy also underlines the commitment of UEMOA countries to use the private sector as an engine of development. The common industrial policy specifically aims at diversifying the region's industrial basis, and preparing local industries for competition at the global level. The implementation of this policy, according to UEMOA's official journal, is expected to allow UEMOA to double its industrial capacity by 2020 . Nonetheless, UEMOA's most significant advances in the area of trade liberalization have been the adoption of a common external tariff (CET) 
and a gradual suppression of custom duties for intra-regional commerce (UEMOA, Official Journal, April 1999).

These two accomplishments represent very significant progress, as they bring UEMOA to the status of a custom union. To implement the CET, products have been classified in four categories with custom rates, varying from $0 \%$ to $20 \%$. As a mechanism to implement circulation of goods and services within the community, the "Regime Tarrifaire Preferentiel Transitoire des Echanges" was introduced to progressively phase out all duties levied on products from member states. Under that system, products originating from countries of the union would be subject to a custom reduction equivalent to $60 \%$ of customs applied to similar products from non-members states (Panafrican News Agency, December 2000).

\section{CONCLUSION}

This chapter has attempted to review the history of Francophone regionalism in West Africa, which culminated in the formation of UEMOA. The earlier form of Francophone integration schemes after independence were the results of intra-Francophone rivalries. Integration projects such as "Le Conseil de L'Entente" and the Mali Federation had a more political than economic significance. With the creation of CEAO, French-speaking regionalism became economically driven, despite its competitive stand against Anglophone states, specifically Nigeria. As the first postcolonial Francophone integration scheme, CEAO was also a manifestation of the first wave of regionalism within that linguistic family in West Africa. Thus, CEAO's achievements and failures are all 
found in its characteristics as a first wave integration scheme. As such, CEAO lacked multidimensionality, limiting its focus to trade liberalization and monetary harmonization.

As a second wave integration scheme, UEMOA is correcting the defects of its predecessor in its multidimensional approach. Nonetheless, despite the adoption of a multidimensional approach to integration as reflected through its treaty objectives, UEMOA has not been capable of significantly broadening the scope of integration. It has been only successful in deepening it, mostly by reinforcing the process of monetary integration.

The creation of UEMOA also symbolizes the transformation of Francophone regionalism from its early competitive approach toward Anglophone West Africa to a more cooperative one. By contrast with previous Francophone schemes, UEMOA was conceived within the spirit of a broader West African integration. Nonetheless, because of the history of Francophone regionalism in West Africa, Francophone integration schemes have continuously been perceived as inherent obstacles to West Africa's integration.

As this chapter has made clear, UEMOA is not a spontaneous creation, but rather it constitutes the final result to date of a long process of economic and political cooperation among Francophone West African countries. Unlike their Anglophone neighbors, Francophone countries of West Africa have a long history of cooperation that dates back to French colonialism. Most researchers have been right when they have noted the "natural tendency" for Francophone states in West Africa to stay grouped. Similarly, the role of France as an active sponsor and 
supporter of French-speaking regionalism in West Africa has been well documented. Even more frequently discussed has been the importance of a linguistic bond among Francophone states. In fact, in many analyses, this linguistic bond has been presented as the single most important factor behind the formation of Francophone regionalism in West Africa.

Those focuses, as important as they are, have obscured some other factors crucial to the formation of Francophone regionalism in West Africa. The geographic contiguity of Francophone states for instance has been largely ignored. In other regions of the world, successful integration or even attempts at integration have been made by neighbors already sharing common borders. This was particularly true for schemes established in the first wave of integration. Just as with the transformation from the CEAO to UEMOA or the one from the E.E.C to the E.U., many second wave integration schemes were simply revitalized schemes from the first wave of integration. Hence, the contiguity of Francophone West African states should not be overlooked in the explanation of the origin of their regionalism. And this is precisely what most differed between Francophone and Anglophone states in West Africa, as in the latter group no two countries shared common borders ${ }^{3}$. Asante (1997:90) points to this specific reason to indicate that the bond among Anglophone states in West Africa at the time of independence was already weaker than the one among other Anglophone states in East Africa, for instance. Anglophone East Africa made at least some efforts to preserve their links after independence. Not surprisingly, Anglophone East Africa has geographical contiguity, just as Francophone West Africa has. 
Also not often taken in consideration when analyzing the reasons behind the formation of Francophone regionalism is simply the economic rationale that motivated these countries to maintain and even expand their ties. As Rapley (1990) explains, the organization of French colonial economy not only did not favor the landlocked colonies, but it further put them in a situation of dependence vis-à-vis the coastal colonies. This dependency requires a maintenance of relations. It is clear that integration among French-speaking countries in West Africa was a matter of necessity rather than choice. This integration was in turn facilitated by the existence of a rich common background. As Lavergne (1997:78) points out, the institutions of Francophone regionalism in West Africa greatly benefited from a number of preexisting ties, which contributed to the deepening of their integration. Their geographic contiguity, their shared membership in the former French West African Federation, their use of a common currency, their high level of intra-zone labor migration, and their use of French as an official language, all contributed to the relative successes of Francophone countries' integration schemes. Although Francophone states could have easily broadened their scope of integration due to their rich common background, they first chose to deepen it because that option was also available. This decision was a judicious one as depth is more difficult to achieve than scope (Smith, 1993:56).

Today, UEMOA's achievements are being built on those of CEAO and UMOA. Although intra-regional trade as a percentage of total exports among UEMOA only represented a low 12.5 percent in 1998 (UNCTAD, 1998), this number still represents by far the highest attained by any regional organization in

\footnotetext{
${ }^{3}$ The exception here is Liberia and Sierra Leone, although they don't share the same colonial history.
} 
Africa. Even more telling is the fact that the total amount of trade flow within the bloc increased by 35 times in the first half of the 1980s without creating trade diversion (Oyejide, 1997:17). The fact that trade flow between the bloc and the rest of the world also increased by 43 percent over the same period, further suggests, according to Oyejide, that UEMOA as an integration scheme is not trade diverting. Trade diversion is a very recurrent criticism of regional integration schemes in general. Francophone regionalism has not been trade diverting, Oyejide reveals, because one of the most significant successes of the defunct CEAO was precisely in the area of trade liberalization. The progress accomplished in this area went far beyond that achieved by other regional organizations in Africa.

As UEMOA's achievements were built on the legacy of CEAO and UMOA, it thus inherited their main advantages compared to other schemes in the region: that advantage is the depth in some areas of integration. CEAO legated the depth in the area of trade liberalization, and UMOA the depth in the monetary and financial sector. The depth of the monetary arrangements inherited by UEMOA confers on it a unique advantage among integration schemes in the world. Since its inception, UEMOA was able to capitalize on its advantage and deepen integration in the monetary sector, as well as in the area of trade liberalization.

With this unique asset, UEMOA's contribution to West Africa's regional integration can be very essential. To be successful, any integration scheme requires depth (Smith, 1993). UEMOA's sophisticated monetary arrangements, as well as its relatively advanced scheme on trade liberalization are important assets that can serve well in a broader sub-regional integration project such as ECOWAS. It is for this 
reason that ECOWAS needs the expertise and the long experience of UEMOA in those two areas to complement its process of regional integration. The depth of UEMOA's schemes is clearly indispensable to ECOWAS to accomplish regional integration in West Africa. 


\section{CHAPTER 2. A TORTUOUS ROAD TO REGIONAL INTEGRATION: THE CREATION OF ECOWAS.}

\section{INTRODUCTION}

This chapter will demonstrate how regional integration in West Africa came about as a result of the collective efforts of both Francophone and Anglophone states. Its relevance is central to the argument of this thesis as it dispels the view that Francophone states' actions inhibit the efforts toward sub-regional integration in West Africa. All Francophone West African nations have recognized the need for greater sub-regional cooperation, and they have demonstrated their willingness to overcome linguistic differences as much as Anglophone states (Aly, 1994:34).

As Asante (1997) notes, the case for regional and sub-regional economic integration and inter-African economic cooperation is indisputable, and has long been recognized. The present fragmentation of African markets emanates from the specific political and economic conditions in which the continent found itself at independence. Precisely because of that fragmentation, economic cooperation is even more relevant to Africa than to any other developing region of the world. Through regional integration, West African economies can become more attractive to foreign industrial capital as they are now losing the race with other emerging economies in other developing regions (Asante, 1997:28).

For this very reason, in the mid 1960s, the Economic Commission for Africa (ECA) in collaboration with the Organization of African Unity (OAU) started to promote economic cooperation initiatives both at the regional and at the sub- 
regional level (Aly, 1994:18). ECA's proposal for economic cooperation in Africa was based on the division of the continent into regions for the purpose of economic development. One of the proposed sub-regional grouping was made of sixteen countries in West Africa (Emeka, 1990:21). The creation of the Economic Community of West African States (ECOWAS) reflected precisely such an initiative. It emerged in the context of the first wave of regionalism that was at the time sweeping through much of the developing world.

The purpose of this chapter is to present and analyze the formation of ECOWAS as a comprehensive integration scheme in West Africa during the first wave of integration. The chapter will present the economic rationales behind the formation of this scheme by highlighting the benefits of economic integration for the entire sub-region. The search for collective economic strength can be seen as a strong rationale for sub-regional integration in West Africa. The following sections of the chapter are devoted to a discussion of the roles of some key players in the process of West Africa's regional integration. The specific role of three key actors in the formation of ECOWAS is discussed.

First, Nigeria's role as the first promoter of a pan-West African integration scheme is analyzed to understand the unique position of that nation in West Africa and its impact on the sub-region. Second, the group Francophone West African states is discussed, as their participation was essential to the establishment of a West African economic community. This section reveals how Francophone states' historic reluctance to associate themselves with Anglophone states, and specifically with Nigeria, shifted over time as a result of a change in their own relations with 
France. Third, the role of France itself is looked at, even though it had a negative role in the integration process. Since France had always encouraged Francophone states not to associate with their Anglophone neighbors, an evolution in the FrancoNigerian relations would inevitably diminish France's opposition to the formation of a West African economic scheme.

The discussion of the role of these key actors subsequently leads us to a discussion of the ECOWAS Treaty which establishes the West African integration scheme. In this section, ECOWAS' objectives and institutions are presented, and its projects and achievements are highlighted. Identifying ECOWAS' major achievements, it is important to note how Francophone states have been involved in every single one of ECOWAS major successes. This point is crucial since the participation of Francophone states in the successful projects of ECOWAS unambiguously demonstrates these states' commitment to the overall organization. The discussion of ECOWAS' projects allows us to identify the broad range of activities in which ECOWAS countries are engaged. This gives us a clear indication of the scope of integration of ECOWAS.

In conclusion, I will argue that ECOWAS' mere existence constitutes an achievement for all West African states. West African states were able to overcome their differences and form an institution promoting their common interests. The fact that Francophone states have not been passive actors in the development of ECOWAS seems to indicate that the institutions they have maintained strictly among themselves do not inherently obstruct ECOWAS' goals of sub-regional integration. 
I will go so far as to argue that it is really their participation which has permitted the expansion of ECOWAS' current scope of integration.

\section{MOTIVES FOR THE FORMATION OF ECOWAS.}

\section{A. The Economic Rationale.}

As Julius Emeka and Stephen Wright (1990) cogently argue, orthodox economics favors the creation of regional integrative blocs to promote industrial growth and trade between countries based on the principle of comparative advantage ${ }^{4}$. They agree that integration in the West African context would lead to a substantial growth in intraregional trade, increased industrial production from programs planned at a sub-regional rather than national level, and potentially a stronger economic and political status vis-à-vis the rest of the world. They further remark that, these positive economic factors would ultimately help to provide West African countries with a more influential voice in world affairs.

Considering its vast resource endowment, Ezenwe (1993) asserts, West Africa as a whole has the potential to gain greater economic autonomy in the world political economy. Although many states of the sub-region occupy territories with poor climatic conditions and an unfavorable topography, West Africa nonetheless represents an important agricultural region in the world. West Africa, for instance, produces more than $50 \%$ of the world output of cocoa. Côte d'Ivoire, the world's leading producer, accounts for nearly $40 \%$. Similarly, the region 
accounts for over $70 \%$ percent of the volume of palm kernels and $30 \%$ of the volume of palm oil entering the world market (Enzenwe, 1993:19). The bulk of groundnuts entering international trade come mostly from two countries in the region, Senegal and Nigeria. Several states of the region are also major producers of other export products such as coffee, sesame, banana, pineapples, kola nuts and cotton (Ezenwe, 1993:17). As countries look for collective strength when integrating, the wide variety of crop available in the sub-region makes an integrated West Africa less marginal on the world economic scene than if individual states went about it their own ways. A coordinated and re-organized production of the crops could also lead to higher productivity for the region. A greater efficiency in regional crop production could then strengthen the overall income earning capacity of the region as a whole.

In addition to these agricultural resources, West Africa's endowment in minerals is equally impressive. Africa produces over 60 per cent of the world production of gold. When South Africa is excluded, the bulk of this production actually comes from West Africa. Africa also accounts for 96 per cent of the world production of diamonds, the bulk of which, outside the Congo and Angola, comes from West Africa. 34 per cent of the world output of manganese is produced in West Africa. The region of West Africa also produces 27 per cent of the world's overall output of iron ore. It has more than a third of the world known deposit of bauxite ${ }^{5}$, and it is one of the world largest crude oil production site, thanks mostly to Nigeria (Ezenwe, 1993:18-21). With all these resources, an integrated West Africa

\footnotetext{
4 The theory of comparative advantage stipulates that countries should concentrate their economic activities in those sectors where their economies are more efficient.
} 
can also acquire more weight in the world economy. The region as a whole could have more leverage in its bilateral negotiations with major outside economic partners such as the E.U. Furthermore, joint investments in the exploitation and export of some of these minerals could raise the income level of countries involved, thus increasing their economic potential (Ezenwe, 1993:23).

There is clearly in West Africa a potential for collective economic strength, but only through genuine integration. So far, the fragmentation that is so characteristic of the entire continent has not permitted West Africa to capture its fair share of power in the world economy. During the early years of independence each West African government took some steps to promote industrial development as a means to bring about a much greater rate of economic growth than what was achieved during colonial times. As every effort was strictly achieved at national levels, none of the development programs initiated during those first decades of independence attempted to coordinate industrial development among the different countries (Asante, 1986:67). For this reason, many projects in the region operated under capacity. For instance, dams, plants, and other industrial projects were duplicated in various countries. This situation never permitted a rationalized use of resources in West Africa. The lack of rational use of resources was among the causes of the slow economic growth in many West African countries. The idea of economic integration in West Africa is geared towards a more rationalized use of resources through the coordination of various development programs at the regional level (Asante, 1986:68).

\footnotetext{
${ }^{5}$ Guinea is the world's largest producer of bauxite.
} 
The new search for wider markets can accommodate large-scale industries and provide an adequate local demand base. This explains the desire of all West African countries to become integrated (Asante, 1986). West African governments have realized that larger markets would allow their industries to expand production and take advantage of economies of scale. In addition, other industries that could not be developed at national levels would have an opportunity to do so in a larger regional market. Above all, as Asante (1986:) further asserts, a larger market would make the sub-region more attractive to foreign capital investment, thus making the area more profitable and more promising for outside industrial investment. Economic integration in West Africa, as Asante concludes, must be seen as " a method providing a more viable basis for economic growth, and more especially for industrialization" (1986:41). Therefore, it does not come as a surprise that the main initiator of West Africa's integration scheme was the region's most heavily industrialized state, Nigeria.

\section{B. The roles of Nigeria and Francophone states in the formation of ECOWAS.}

Among West African states, Nigeria stands out because of its size. As the most populous nation on the continent, Nigeria has approximately 110 million people. This is more than the combined population of the fifteen remaining states of West Africa. Nigeria's economic weight in the sub-region is also illustrated by the fact that it accounts for nearly 70 per cent of the region's total Gross Domestic Product and it represents over 65 per cent of its export (ECOWAS, 2000). Clearly, Nigeria's economic domination over West Africa cannot be overstated. 
In the early 1970s, Nigeria found itself in an economic boom largely due to the increase in crude oil exports and the rise in oil prices following the 1973 oil shock. The country's leadership at that time had the vision of a more evenly developed West African region in which Nigeria would not be a resentmentprovoking economic giant amid a sub-regional "economic desert" (Gambari, 1990:15). It is at that time that Nigeria established the Nigeria Special Fund (NSF) ${ }^{6}$ in the African Development Bank. Far from following pure altruistic considerations, Nigeria's motivations in championing West African integration were also selfinterested. The integration of West African economies was seen by Nigeria as a guarantee of increased market access to sustain its new industrialization. (Gambari, 1991:19). Furthermore, an economic community could also open up new venues for the deployment of Nigeria's very enterprising manpower.

For all these reasons, one can understand Aly's point $(1994 ; 28)$ that it was immediately following the independence that Nigeria's leaders started to dream of establishing a Nigerian-led form of pan-West African cooperation which would embrace all the countries of the sub-region. As Aly explains, Nigerian leaders dreamed of such a comprehensive West African integration project because they saw themselves as the "natural leaders" for such scheme. They had already suggested the establishment of a West African Economic Community in the early 1960's (Aly, 1994:33). However, the irruption of civil war, and the secession of Biafra would temporarily halt this project.

\footnotetext{
6 The NSF can be considered as Nigeria's foreign aid to the poorest African countries. The fund was established through the African Development Bank to provide preferential loans to the least developed member states of the bank.
} 
After the end of its civil war, Nigeria reactivated its initiatives to create an economic community in West Africa. The experience of the civil war sharpened Nigeria's realization of the imperative need to develop more links with its West African neighbors. The alarming fact for Nigeria was that two West African countries were among the four nations that had recognized the secession of Biafra during the civil war (Gambari, 1991:19). Reassessing its foreign policy after a civil war, Nigeria concluded that Africa had to be the "centre-piece" of its new diplomacy. By implication, Gambari (1991) suggests, West Africa therefore became the focus of the country's new diplomatic activities. For Nigeria, it was crucial to take appropriate measures to ensure that West African countries would never again be staging the ground for an extra-regional power's attempt to destabilize or disintegrate the country. The fact that France used its considerable power over Francophone states, particularly Côte d'Ivoire, for negative influence during the Biafra war, was of singular concern for Nigeria.

For Nigeria, a very important political reason for initiating the creation of ECOWAS was to subvert the French political influence over the Francophone countries in the sub-region. To achieve this goal, Nigeria understood the urgent need to bring Francophone states closer to it. In order to accomplish this objective, Nigeria first established a cooperation agreement with the smallest Francophone state of the sub-region, Togo.

Emeka and other analysts such as Lavergne and Gambari recognize that there has long been a fear among West African countries, particularly the Frenchspeaking ones, that too close an association with Nigeria would be dangerous. The 
reluctance of Francophone states to join an association with Nigeria was due in part to Nigeria's large population, and economic and political weight, which all seemed to indicate a potential for Nigeria to dominate any future sub-regional organization (Emeka, 1990:26). As discussed in the previous chapter, it was in part the need to counterbalance Nigeria's economic domination that prompted Francophone West African states' integration initiatives during the first round of integration.

Well aware of this situation, and to demonstrate that it had no desire for region-wide domination, Nigeria chose to associate itself with Togo ${ }^{7}$. In 1974, Nigeria and Togo established an economic union. The Nigeria-Togo agreement was characterized by the pursuit of objectives capable of early realization, and by the adoption of an open-door policy that would enable all countries of the sub-region to latter join the agreement. The adoption of these principles reflected both parties' understanding of the need to fashion a scheme that would be attentive to the peculiar needs of West Africa (Asante, 1986:89).

The political purpose of the Nigerian-Togolese union was to demonstrate by effect that a small and relatively poor country could engage in an economically rewarding relationship with a large and rich country. This demonstration by effect had two specific goals. The first goal of this union was more obvious: to reduce the fear of domination on the part of smaller and poorer countries that were still being approached to participate in a broader pan-West African economic union. The second objective of this union was to demonstrate that official language differences did not constitute an insurmountable barrier to trade and economic relationships among West African countries (Gambari, 1991:47). 
The Togo-Nigeria union was thus conceived as the nucleus for a larger West African Community. The dependence of the neighboring countries of Benin and Niger on Nigeria's economy, and the opportunity for expanded trade and investments made it difficult for them to resist Nigeria's call for economic integration. Other CEAO/UMOA countries finally agreed in 1975 to participate in a new West African Community as long as their own organization's continued existence was not directly put in jeopardy (Gambari, 1991:59).

The Nigerian diplomatic offensive for the formation of a West African economic community coincided with a period when a growing number of Francophone states - in particular Benin, Niger and Mauritania- began to denounce some of the cooperation agreements with France as a neo-colonial, straightjackets, and an infringement of their sovereignty (Asante, 1986:53). The overall demands for reforms in cooperation agreements showed a desire for greater independence vis-à- vis France.

Despite their growing criticism of some of the continued agreements with France, Francophone states still maintained most of their links with France. On the other hand, perhaps to provide a counterbalance, Francophone states also accepted to join Nigeria in an economic union. This strategy was sought to maintain a certain balance between Nigeria's growing power and France's enduring neocolonial hegemony. In a sense, Nigeria's increased wealth from the oil boom started to take away France's position as the "undisputed hegemon" in the sub-region. Asante (1986:39) notes that France's position declined in importance as the weight of oil

${ }^{7}$ Togo is the smallest Francophone state (both in terms of size and population) in West Africa. 
rich Nigeria continued to increase. This new "superpower" competition in the region had a significant impact on the formation of ECOWAS.

\section{France and the Formation of ECOWAS.}

France has played a significant role in the process of West African integration, although this role has not always been a positive one (Gambari, 191:33). The symbiotic relationship between France and the Francophone states has very often been regarded as an obstacle to a larger West African integration. Following such reasoning, Nigeria considered it necessary to weaken at least, if not totally break the existing ties between France and her former colonies in the region. France, on the other hand, encouraged the Francophone states to establish their own economic schemes to counterbalance the "heavy weight" of Nigeria in West Africa (Gambari, 1991:48).

The pursuit by France of a 'privileged and exclusive' relationship with sub-Saharan Francophone states in West Africa has been geared toward maintaining a zone of influence or "chasse gardée" out of the reach of other Western states, also beyond the reach of Nigeria's ambitious regional hegemony (Onwuka, 1989:188). French President De Gaulle's hostility toward Nigeria, Onwuka observes, could be seen in his determination to dismantle the 'giant federation' during the civil war in order to check its eventual emergence as a rival to France in the sub-region. Francophone West African states' own fear of Nigeria's domination at the time facilitated the implementation of De Gaulle's policy. 
As Ojo observes, the fact that Francophone states themselves asked for a revision of the cooperation agreements with France suggests that the utility to them of the policy of exclusivity was at least doubtful. After the revision of the cooperation agreements in the early 1970's, France also came to realize the potential danger of limiting its relations in the continent to only the Francophone states. Thus, France decided to overcome these self-imposed limitations by seeking to widen its field of influence (Ojo, 1987:89)

It was after De Gaulle's departure, and under President Georges Pompidou, that overtures toward non-Francophone states were initiated. In an increasingly competitive commercial environment among industrialized countries, especially in Europe, Pompidou's administration realized that France could not continuously ignore the vast market that existed outside its traditional sphere of influence in Africa (Onwuka, 1989: 193). As Nigeria was emerging as an important oil producer, it became impossible for France to ignore the potential such a country represented for French investment and exports. The Arab oil boycott of 1973-1974, and the generally tense political situation in the Middle-East at the time, ended up making Nigeria an important supplier of oil to France. As a result, an unprecedented level of commercial relations between the two countries developed. By 1975, France was already getting close to 20 per cent of its oil from Nigeria. In addition, French company Elf Aquitaine became one of the three major firms drilling oil in Nigeria (Onwuka, 1989: 199).

Major French conglomerates such as Bouigues also became heavily involved in various sectors of the Nigerian economy. French car-maker Peugeot even 
opened its largest African assembly line in Nigeria. By 1976, the volume of Franco-Nigerian commercial exchanges had surpassed those of France's exchanges with any other sub-Saharan country, including the traditional Francophone partners. France's exports to Nigeria in 1980 totaled $\$ 1.483$ billion and its imports were estimated at $\$ 2.718$ billion. By contrast, for the same year, France's exports to Côte d'Ivoire and Senegal, its two leading partners in Francophone Africa, were respectively $\$ 1,251$ million, and $\$ 415$ million. France imports from the two countries were also respectively, $\$ 714$ million and $\$ 188$ million (Direction of Trade, 1980). Hence, by the early 1980s, France had simply emerged as Nigeria's second supplier after Britain, and as its second customer after the United States (Ojo, 1987:91).

On the political front, as Onukwa remarks, France had come a long way, as it started to perceive Nigeria no longer as a rival but rather as a partner and stabilizing force in West Africa. France for instance, tried to get Nigeria involved in the Chadian conflict in which it was implicated. France also tried to have Nigeria act more actively as a counterweight to what was then perceived as Libya's subSaharan ambitions (Nwokedi, 1989: 99). For Nigeria, on the other hand, the perceived benefit of these expanding relations with France was a rapprochement with the Francophone states of the sub-region. Nigeria and Côte d'Ivoire, whose relations had deteriorated greatly during the civil war, were eventually able to resume normal diplomatic relations (Onukwa, 1989:191).

In light of all these developments in the Franco-Nigerian relations, France slowly but surely abandoned its opposition to the establishment of a pan-West 
African community led by Nigeria. Because of France's own dealings with Nigeria, a West African community dominated by Nigeria was no longer seen as such a threat by France. The main thing France insisted on was to maintain the Francophone bloc of countries united. This new policy was illustrated by the informal 'green light' given by France to CEAO/UMOA states to finally join ECOWAS, as long as they maintained their own integration schemes.

\section{THE TREATY OF ECOWAS.}

The vanishing of the French opposition to greater sub-regional integration in West Africa was significantly marked by the adoption of the Lomé Convention in February 1975. The Lomé Convention was the first trade agreement between European countries and all their former colonies. The Convention essentially granted to the former colonies preferential treatments for market access in Europe. The Lomé Convention represented the first instance of a joint negotiation by all former colonies with their outside economic partners. As Asante (1986:31) accurately remarks, the EEC might have contributed to past trade and economic divisions within Africa. But the Lomé Convention in a real sense reunited African nations in a common endeavor. As French-speaking and English-speaking countries came together for a long negotiation process that culminated with the signature of the Lomé Treaty, they forged a sense of common destiny, and realized the need to cooperate on common economic issues. As Asante simply concludes, they acknowledge that "If all countries in West Africa could come together to sign an agreement to promote trade 
with the EEC, it ought to be possible for them to conclude an agreement for the same ends within the sub-region" (1986:54).

This is precisely what happened a few months later, on June 23, 1975. On that day, all fifteen West African head of states met in Lagos, Nigeria to sign the ECOWAS Treaty. As it had been the case with the signing of the Lomé Treaty previously, West African leaders had clearly realized the need for their countries to link their economies together. In fact, as McCormick (1999:13) notes, the post-war progress toward integration and regional cooperation in Europe had a considerable impact on many developing countries. Many Third World leaders eventually espoused the "new" concept of regional economic integration. The signing of ECOWAS was a manifestation of the first wave of regionalism in Africa. The ECOWAS Treaty is thus considered by many analysts, not only as the most ambitious regional integration scheme in Africa, but also as the first serious attempt at economic integration and cooperation in the whole sub-region of West Africa (Asante, 1986:33). The overall objectives of the treaty was to promote cooperation and integration among West African countries in order to ensure growth and development.

Seven specific objectives are discernible from the ECOWAS Treaty. Those specific objectives are :

- Elimination of custom duties.

- Abolition of quantitative and qualitative restrictions on trade.

- Establishment of common tariffs and common commercial policies. 
- The abolition of obstacles to free movement of persons, services, and capital.

- The harmonization of industrial and agricultural policies.

- The establishment of a fund for cooperation.

- The harmonization of monetary policy.

As was typical with most first wave integration schemes, all the objectives contained in ECOWAS Treaty were purely economic. Just as was the case in Europe in the early stages of its integration, trade liberalization was also the area of focus in the integration process for ECOWAS (Diouf, 1985:56). Nevertheless, unlike Europe, those efforts towards integration never materialized with ECOWAS. In fact, as eventually happened with most integration schemes among developing countries in the first wave of integration, ECOWAS became moribund shortly after its establishment in spite of all the high hopes and expectations at the time of its Treaty. This situation lasted until the early 1990 s.

The early 1990's brought a new enthusiasm for regional integration in Africa as well as in others developing regions of the world. Many factors explained the resurgence of this interest for regional integration in spite of all past failures. The formations of new powerful trading and economic blocs such as the European Union Single Market and NAFTA appear to be one of the factors that fostered this trend among developing countries. The intense globalization of the world economy made the formation of trading blocs essential in many countries' development strategies. In West Africa, this new enthusiasm for integration led to a revitalization of ECOWAS. A Revised Treaty was signed in 1993. Highlighting a new approach to 
integration, the Revised Treaty introduced the principle of supranationality in the application of the decisions, and the extension of the scope of the community programs to other areas such as transportation, communication, environment, security, monetary and financial policies (Bandu, 1999: 76). This transformation of ECOWAS marked the irruption of the second wave of regionalism in the sub-region. With its Revised Treaty, ECOWAS' approach to regional integration became multidimensional, an important characteristic of second wave integration schemes. The multidimensional aspect of ECOWAS' approach to integration since the adoption of its Revised Treaty is reflected by the broad scope of its activities. The discussion on ECOWAS' activities that will follow clearly demonstrate this point.

Another specific aspect of the Revised Treaty worth noting is the fact that it defined ECOWAS as ultimately the sole economic community in the sub-region. It also clearly spelled out ECOWAS' relationship with other West African IGOs, including UEMOA (then CEAO), asking for complementary relations. A specific objective contained in the Revised Treaty is the decision to work toward the creation of a single monetary zone in the sub-region (ECOWAS, 2000). The new institutions of ECOWAS are as follow:

- The Authority of Heads of State and Government of Member States, which is the supreme organ of the community. It is responsible for the general direction and control of the community, and takes all measures to ensure the progressive development and the realization of its objectives.

- The Council of Ministers which is comprised of the Ministers in charge of ECOWAS or any other Minister of Member States. The Council is responsible for 
the functioning and development of the community, and to this end, it makes recommendations to the Authority of Head of States on any action aimed at attaining the objective of the community. It also issues directives on matters concerning coordination and harmonization of economic integration policies.

- The Executive Secretariat, headed by an Executive Secretary appointed for a four year term. The Executive Secretariat, comprised of various commissions, monitors and facilitates the application of the provisions of the Treaty and the related Protocols of the Community. It also ensures the harmonization of the projects and programs of the Community. In addition, the Executive Secretariat can prepare Community projects and programs on its own initiative or at the request of the Council of Ministers.

- The Fund for Cooperation and Compensation which provides compensation and other forms of assistance to Member States that have suffered from losses as a result of the application of the provisions of the Treaty. The Fund also promotes development projects in the poorest Member States of the Community (i.e., Mali, Burkina Faso, Niger).

- The Court of Justice, which ensures the observance of law and justice, interprets the provisions of the Treaty, and settles disputes referred to it.

In addition to these established institutions, the revised Treaty of ECOWAS also provides for the establishment of a West African Parliament and an Economic and Social Council. An interparliamentary committee has been put in place in a transitory process toward the establishment of the Community Parliament. The 
interparliamentary committee is composed of elected parliamentarians from member states' national assemblies (ECOWAS, 2000).

\section{ECOWAS' ACHIEVEMENTS}

After having cited UEMOA's achievements in the previous chapter, it is necessary also to note ECOWAS' own achievement in order to compare the different performance of the two organizations. In the previous chapter, we saw how deep UEMOA's integration is. In this chapter we will see how broad the scope of ECOWAS' activities is. This point of comparison will allow us to demonstrate later how UEMOA's depth can complement ECOWAS' scope in achieving West Africa's regional integration.

ECOWAS' achievements have been assessed in very different manners. One way to measure ECOWAS' progress has been to compare it to UEMOA. On those grounds the consensus is that, on general matters of micro-economic integration and policy harmonization, ECOWAS has been trailing UEMOA. The fact that ECOWAS lacks a common currency, a history of cooperation among its members, and a convergent judicial system is given as a reason for its inability to make "deep" progress in some areas of economic integration, unlike what UEMOA has done (Bandu, 1997:17). ECOWAS' performance has also been judged in terms of its own market integration objectives. Even with this regard, there appears also to be an agreement that ECOWAS has not completely met its own objectives of market integration (Oyejide, 1997:89). 
Still, as Oyejide (1997) suggests, ECOWAS' objectives must be assessed not solely in terms of market integration but also in terms of its broader developmental goals. Following Oyejide, I will adopt this third approach of assessing ECOWAS' achievements. I follow this approach because, since the adoption of its Revised Treaty, ECOWAS has incorporated broader development goals that goes beyond the basic objectives of market integration. As has already been noted, ECOWAS' first decade and a half under the first wave of regionalism was not particularly successful. It is only under the second wave of integration, symbolized by the adoption of the Revised Treaty in 1993, that significant advances started to be seen, particularly in the domain of achieving broader community objectives. In the new wave of regionalism, ECOWAS adopted a fast-track approach to regional integration. (ECOWAS, 2000).

A major undertaking of ECOWAS has been the implementation of its protocol on the free movement of people, their right of residence and of establishment. Visa-free travel has been achieved, and the right of establishment is also widely applied in the community (Bundu, 1997:22). All West African citizens have now the right to legally reside in any country of their choice within the community. A travel certificate was introduced, to be used as a legal travel document within the subregion. In May 2000, the ECOWAS passport was introduced, and is used along with national passports for a transitory period of five years (ECOWAS, 2000). The introduction of the passport is in line with the Community protocol on the right of residence and establishment. Harmonized custom documents were also introduced 
and are already being used in twelve states ${ }^{8}$, half of which are French-speaking. Some French-speaking countries are indeed among the countries that most readily implemented these new ECOWAS' resolutions (Panafrican News Agency, 2000). The implementation of this particular protocol on harmonized travel documents has had a great impact on the working life of trade unions, labor groups and organizations, traders, and especially market women who frequently cross borders. Asante had already recognized a few years earlier the positive impact the implementation of this protocol could have on various social groups in West Africa (Asante, 1996:174).

Recognizing that the free movement of persons, goods and services in the region depends on effective physical cohesion, ECOWAS has also embarked on a very ambitious project of revamping regional development infrastructures. This new regional infrastructures program primarily seeks to establish a West African Highway Network (ECOWAS, 2000). The first phase of the program consists in the building of a Transcoastal Highway from Lagos, Nigeria to Nouakchott, Mauritania, and a Trans-Sahelian Highway from Dakar, Senegal to N'Djamena, Chad. The Transcoastal Highway which consists of $3,800 \mathrm{~km}$ of road is 83 per cent completed. The Trans-Sahelian Highway which consists of $3,894 \mathrm{~km}$ is 88 per cent completed. The second phase of the project, which is about to be undertaken, involves the construction of highways and land corridors that will link landlocked countries to the coast. In addition, a plan was adopted to establish railway linking Lagos - Cotonou - Lomé - Accra - Niamey - Ouagadougou (ECOWAS, 2000).

\footnotetext{
${ }^{8}$ Benin, Burkina Faso, Gambia, Ghana, Guinea, Guinea Bissau, Mali, Niger, Nigeria, Senegal, Sierra Leone, and Togo.
} 
Outside the domain of transportation, ECOWAS' work of integrating West Africa and broadening the scope of its development has also been very impressive in the area of Telecommunication. By completing the West African portion of the Pan African Telecommunication Network, all West African countries now have the ability to be linked by direct telephone, telex, and fax connection (ECOWAS, 2000).

Another major undertaking of ECOWAS is the construction, now underway, of a West African gas pipeline that will link Nigeria, Benin, Togo, Ghana, and Côte d'Ivoire in its first phase before being expanded to other member countries. This project is part of a full program aimed at rationalizing the production and distribution of oil and oil related products in the region. According to Lansana Kouyaté ${ }^{9}$, this program is meant to ensure a constant and reliable supply of energy at a reasonable price (Seidman 1992: 47). Similarly, action was also undertaken to accelerate interconnection of electricity grid by implementing a $330 \mathrm{kv}$ connection between Ghana, Togo, Benin, and Nigeria. This last program reflects the fact that ECOWAS, similar to other more advanced integration schemes such as the E.U, also has an energy policy. Clearly, ECOWAS' existing or planned activities are broad in scope.

After the Revised Treaty was adopted monetary integration also became one of ECOWAS' main goals. ECOWAS has since then instituted a West African Monetary Agency (WAMA) to coordinate the process of monetary integration. WAMA facilitates intraregional transactions and reduces the use of foreign convertible currencies. The Agency is also responsible for ECOWAS' monetary program, which has the specific objective of creating a single monetary zone with 
a common currency. The single currency would replace the nine currencies currently in existence (the CFA Franc and the eight inconvertible currencies used by non-UEMOA countries) (Lavergne, 1997: 122). As a first step toward realizing this goal, ECOWAS Travelers Checks were first introduced in 1998. In the process of establishing a single currency, ECOWAS countries have decided to create a second monetary zone with a common currency for all English-speaking countries $^{10}$ plus Guinea (ECOWAS, 2000).

This second monetary zone is supposed to be in place by the end of 2001 . The two zones will later be merged to create a single monetary union in 2004 , thus completing the process of monetary integration (Panafrican News Agency, 2000). To facilitate this development a single central bank will also be established. It is thus obvious that ECOWAS has taken some very decisive step toward its goal of subregional monetary integration despite its lack of previous experience or success in this area.

As the West African banking industry has been historically dominated by foreign-owned and state-owned banks, there were virtually no local private commercial banks until recently. This situation lasted until 1988 when ECOWAS sponsored the creation of ECOBANK. ECOBANK became the first bank-holding company in West Africa with more than 1200 shareholders from fourteen countries in the sub-region (ECOBANK, 2000). An exceptional occurrence in West Africa, its initial start-up capital was entirely raised from individual and institutional shareholders in the sub-region. It is important to note that ECOBANK's single

\footnotetext{
9 ECOWAS current Managing Director.

${ }^{10}$ Ghana, Gambia, Sierra Leone, Liberia and Nigeria.
} 
largest shareholder is the Fund for Cooperation, Compensation and Development (FCCD), ECOWAS' development and financial arm. Now in operation for 13 years, ECOBANK has 42 regional branches in 11 West African countries, both Francophone and Anglophone nations (ECOBANK, 2000).

The establishment of ECOBANK clearly gives an impetus to the private sector's role in sub-regional economic integration. The enthusiastic response of the West African business community to ECOBANK further illustrates the collective desire of West African citizens to bridge their cultural and linguistic differences, and to fully participate in the process of integration. The creation of ECOBANK reflects ECOWAS' ability to involve directly the citizens of West Africa in the integration process, thus crossing the boundaries of linguistic and cultural differences (Bundu, 1999:33). The creation of ECOBANK is another benefit of ECOWAS' multidimensional approach to implement integration.

Another illustration of ECOWAS' positive impact on the integration of the West African private sector is the recent establishment of ECOAIR. ECOAIR was conceived as the first regional private airline in West Africa. Just as with ECOBANK, ECOWAS' financial arm, the FCCD also subscribed as a major shareholder in the new company's start-up capital. Once again, this project has created interest in both Francophone and Anglophone states, as participants in the start-up capital are from Burkina Faso, Cote d'Ivoire, Ghana, Nigeria and Senegal. ECOWAS has facilitated the establishment of the company by obtaining all permissions (i.e., landing rights, overflight permits) necessary for ECOAIR to operate as an airline in each member state. ECOAIR's inaugural flight symbolically 
coincided with the last summit of ECOWAS' Heads of State and Government in December 2000 in Bamako, Mali (ECOWAS, 2000).

Further illustrating this particular capacity of ECOWAS to multiply its areas of integration is the fact that it has encouraged the formation of a great number of associations involving West African citizens. Such associations include the West African Youth Union, the West African Women's Association, and the West African Worker's Union. In addition, ECOWAS has encouraged the formation of a number of regional business associations such as the Federation of West African Chambers of Commerce, the Federation of West African Manufacturers Associations, the West African Banks' Association, and the Union of West African Road Transporters (ECOWAS, 2000). Although most of these organizations are officially independent from ECOWAS, they nonetheless represent an impressive array of regional organizations sponsored or created with ECOWAS' help. They further illustrates the broad range of sectors in which ECOWAS has been involved in its efforts to integrate West Africa. The policies and programs initiated by these NGOs and other associations provide a social foundation on which ECOWAS can further consolidate its process of regional integration.

As a multidimensional economic integration scheme with broad scope, it should not come as much of a surprise that one of ECOWAS' biggest accomplishments is actually in the political domain: specifically, in the domain of security. Although there was no provision in the ECOWAS Treaty for regional cooperation in defense and political matters, the need to create an atmosphere of confidence and trust throughout the region as a precondition for regional integration 
was felt soon after the community became operational (Bundu, 1997:156). As a result, new protocols on Non-Aggression and on Mutual Assistance in Defense were adopted. But, unfortunately, because of the lack of a multidimensional approach during the first wave of integration, these protocols on defense and security did not get the chance to be implemented for the longest time. Meanwhile, in the $1980 \mathrm{~s}$ political tensions within and among various member states kept rising. For this reason, in its $16^{\text {th }}$ Annual Summit in 1993, and as an integral part of the Revised Treaty, ECOWAS' member states signed a new protocol making the resolution of regional conflicts one of the main objectives of the organization. Following this decision, the ECOWAS Cease Fire and Monitoring Group (ECOMOG) was created (ECOWAS, 2000). This was done with the realization that regional security issues could no longer be separated from issues of economic development. This decision was indeed very consistent with the approach common to new regionalist schemes, as was previously witnessed in Asia, Latin America and in Europe where security issues were being fused with issues of economic integration (Fawcett, 1996:123).

ECOMOG's very first mission was in Liberia where it was deployed with contributing troops from eight countries ${ }^{11}$, both Francophone and Anglophone, and under the military command of a Nigerian general. The operation lasted five years, and ECOMOG left the country after imposing a cease-fire, disarming the factions, and organizing and supervising a new election (ECOWAS, 2000). This first success of ECOMOG was applauded as a first case of African military solution to African problems (Panafrican News Agency, 2000).

\footnotetext{
${ }^{11}$ Benin, Burkina Faso, Gambia, Ghana, Guinea, Mali, Niger, Nigeria, Sierra Leone, and Senegal.
} 
ECOMOG's second successful intervention was in 1997 in Sierra Leone, where it was able to restore peace and allow the organization of democratic elections. Furthermore, ECOMOG brought back in office the newly elected president of Sierra-Leone, Tejan Kabbah, after he had been overthrown by a coup d'état a year after his election (ECOWAS, 2000). Another minor intervention of ECOMOG was the implementation of a cease fire in Guinea Bissau in 1999. Currently, ECOMOG is being deployed at the frontiers of Liberia, Sierra Leone and Guinea, to prevent an escalation of the new conflict in the area (Panafrican News Agency, 2001). The interventions in Liberia and Sierra Leone appear retrospectively today as only short term victories for ECOMOG as complete peace and stability was not restored in the sub-region.

Nonetheless, with ECOMOG, ECOWAS has gained a unique credibility on the international scene for its efforts toward peacekeeping in West Africa. This new credibility of ECOWAS in matters of security is illustrated by the fact that Western countries that have become wary of interventions on the African continent have shown a great deal of enthusiasm in assisting ECOWAS financially and materially in its peacekeeping activities (Panafrican News Agency, 2000). The U.S. initiative announced during president Clinton's visit to Nigeria to provide specific training to Nigerian troops in the domain of peacekeeping is a blatant illustration of this phenomeon. This new training is part of a program established by the U.N. to reinforce ECOMOG's own peacekeeping capabilities. Under this program, five Nigerian battalions are to be trained and to receive uniforms, weapons, communication equipment, and transport supplies from the United States. In 
addition, one battalion each from Ghana and Senegal will receive a similar training from the United States Special Forces (ECOWAS, 2000). The participation of Senegal in this program clearly reveals the commitment of Francophone states to ECOWAS' overall projects. Senegal is a significant French ally. It still hosts France's most important military base in the sub-region. And yet, Senegal is willing to take part in ECOMOG's new ventures (Panafrican News Agency, 2000).

\section{CONCLUSION}

As has been revealed in this chapter, ECOWAS' integration activities cover a large array of sectors. Since the signing of the Revised Treaty, which marked the beginning of the second wave of integration in the sub-region, ECOWAS has become a more dynamic organization. Its strength has since been its ability to get involved in different political, economic, and social sectors in West Africa. Having been able to enlarge the scope of integration within the sub-region indisputably constitutes a major achievement for ECOWAS.

It is no doubt an achievement that fifteen developing nations have been able to agree on common schemes for free trade, the free movement of people, a monetary union, a regional defense cooperation, and the joint development of regional transports network infrastructures. These accomplishments mark the solidarity and the sense of common destiny that have finally reached West African countries despite the initial differences in cultural and linguistic backgrounds. 
But the creation of ECOWAS can also be seen as an expression of West African countries' awareness of the fact that the present international economic system requires wider regional blocs of economic cooperation (Asante, 1986). Through ECOWAS, the countries of West Africa have now found "a new common future" in a world that is increasingly becoming small and interdependent. This challenge of external dependency has finally allowed Francophone and Anglophone states in West Africa to unite in search for a common destiny.

The history of ECOWAS reveals that its existence as well as its recent accomplishments are all direct results of the collective desire of West African states to increase their cooperation and reduce their dependency vis-à-vis the external world. Despite their historic reluctance to engage in wider sub-regional integration, Francophone states are now key participants in West Africa's current integration efforts. In fact, without Francophone states' participation in the project, ECOWAS' broad scope of integration would have been more difficult to achieve. Nonetheless, the parallel existence of the institutions of Francophone regionalism sometimes continues to be seen by some as an expression of the Francophone states' lack of commitment toward ECOWAS. Still, the Francophone states unambiguously stated their commitment to ECOWAS. They have affirmed that ECOWAS is ultimately the only integration scheme in the sub-region. As was noted in the previous chapter, UEMOA now places its objectives within the broader framework of ECOWAS. The view of the Francophone states on their dual membership in ECOWAS and the Francophone institutions is best expressed by former Senegalese President Abdou Diouf who said: "It is everybody's interest that if ECOWAS reaches its cruising 
speed, the CEAO should normally melt into the structures of ECOWAS. We are convinced that the future is with ECOWAS. What we members of CEAO do not want, is to be asked to eliminate something that works well, that produces brilliant results, while ECOWAS has not reached cruising speed." (Asante, 1986:167). 


\section{CHAPTER 3. ECOWAS-UEMOA：CONFLICT OR COOPERATION?}

\section{INTRODUCTION}

A politically sensitive issue confronting West African nations is the parallel existence of ECOWAS and UEMOA, and the interlocking relationships between the two. This is the case because member states of UEMOA are also signatories of ECOWAS. The question that this situation raises is the compatibility of the two integration schemes. Although advocates of UEMOA deny the antithetical relationship between the two schemes, their marriage is certainly not an obvious one. The high level of international support for UEMOA has been viewed with mixed or sometimes hostile feelings by advocates of ECOWAS who feel that UEMOA's projects are being used by donors to undermine the more ambitious programs of ECOWAS.

The purpose of this chapter is to show that UEMOA and ECOWAS can indeed complement each other in a general process of West African integration. This conclusion will be reached after showing that both schemes do not differ much in terms of their broad integration objectives. I will show that the difference between the two schemes lies rather in their approach toward achieving their common goal. Generally, UEMOA has focused its efforts on deepening some of its arrangements, specifically in the monetary area, while ECOWAS has worked consistently more on broadening the scope of its integration. As a result, it appears that the combination of UEMOA's depth and ECOWAS' scope makes both schemes complementary in the general process of West African integration. 
To begin, the chapter will first present different arguments that have been made to demonstrate the incompatibility of the two economic integration schemes in the sub-region. These arguments are essentially cases made against UEMOA, which is still seen by many as an inherent obstacle to regional integration in West Africa. This chapter will first analyze whether the existence of UEMOA constitutes an obstacle to West Africa's regional integration as sought by ECOWAS. In performing this analysis, I will classify authors into two groups based on their way of accessing the incompatibility between UEMOA and ECOWAS. The first approach focuses on the inherent contradictions contained in the treaties of the two organizations. The second approach argues that the incompatibility stems from a certain form of redundancy between the two treaties.

The next section will discuss ECOWAS' own shortcomings, and demonstrate that the Francophone states are not solely responsible for them. In fact, I will argue that Francophone states do not share a high proportion of the blame for the possible failures of ECOWAS. A close analysis of some of ECOWAS' reported failings will instead put the blame on some of ECOWAS' Anglophone states. In the end, I will show that the responsibility for both ECOWAS' successes and failures is by and large equally shared by both Francophone and Anglophone states.

Having demonstrated that the Francophone states of UEMOA are not collectively responsible for some of ECOWAS' disappointing results, the last section of the chapter will evaluate how ECOWAS and UEMOA can cooperate for the overall benefit of West Africa's integration. More specifically, this section will analyze how UEMOA's depth can complement ECOWAS' scope in the process of 
sub-regional economic integration. It will be made clear that UEMOA's existence has not impeded ECOWAS' work on sub-regional integration in West Africa.

\section{POTENTIAL FOR CONFLICT AND REDUNDANCY BETWEEN UEMOA AND ECOWAS.}

Many analysts, among them Jeffrey Fine, Stephen Yao, S.K. B. Asante and Amhad Ali, have pointed to potential sources of conflict between ECOWAS and UEMOA. Stephen Yao and Jeffrey Fine have focused on the contradictions contained in the treaties establishing both schemes to illustrate their incompatibility. Meanwhile, Asante and Aly, among others, have looked at the similarities between the UEMOA treaty and the ECOWAS treaty to identify some redundancies between them. In both cases, these analysts converge on the view that UEMOA's existence constitutes an obstacle to the efforts toward sub-regional integration pursued by ECOWAS. A first section of this chapter will present both views, while the second section is devoted to rebutting these view.

For Jeffrey Fine (1997) and Stephen Yeo (1997), French-speaking regionalism has negative political consequences for economic cooperation and integration efforts being currently undertaken in West Africa. Based on these authors' views, UEMOA and ECOWAS are clearly incompatible. For these authors, their incompatibility is derived from the fact that UEMOA's treaty contains elements that appear to be in contradiction with ECOWAS' own objectives. 
As was previously discussed, Francophone regionalism was spurred by the desire of French-speaking countries in West Africa to counterbalance Nigeria's regional domination. The institutions of $\mathrm{CEAO} / \mathrm{UMOA}$ were created in that context during a first wave of regionalism. However, the transformation of CEAO and UMOA into UEMOA in a second wave of regional integration reflected the desire of Francophone states not only to make their integration scheme more dynamic, but also to make it appealing as an attractive center of economic activities for other nations of the region, including non-French-speaking states. For this specific reason, the UEMOA treaty, unlike CEAO's, provides for the accession of other West African states in addition to the original members of this monetary union. With this clause, UEMOA appears to be positioning itself potentially as a comprehensive integration scheme for the entire sub-region of West Africa, just as ECOWAS is intending to do (Fine, 1997:45).

The problem that this situation poses according to Fine and Yeo is that it confronts non-Francophone states with the decision of whether to join UEMOA or to stay committed to ECOWAS. Soon after the transformation of UMOA into UEMOA, Ghana was exactly in such situation as its leaders contemplated whether to join UEMOA or not. The Ghanaian government had even gone as far as to put in place a special commission to study the mechanisms of UEMOA in order to evaluate the possibilities of Ghana's entry into the CFA zone. After several years of "evaluation", Ghana eventually opted instead for the formation of a new monetary zone with Nigeria (Panafrican News Agency, 2000). Although Ghana did not finally join UEMOA, the fact that it had the opportunity constitutes for Yeo and Fine an 
illustration of the potential UEMOA has to take away Anglophone states' commitment to ECOWAS.

Asante (1997:89), on the other hand, identifies a form of redundancy between the UEMOA and the ECOWAS treaties. Pointing to the redundancy between the treaties, Asante even asks if the creation of UEMOA was indeed necessary. In his view, there is really no crucial difference between UEMOA and ECOWAS (since the Revised Treaty) in terms of their objectives. This observation is actually confirmed when one looks at the objectives outlined in the two treaties. The similarities between both treaties is certainly explained by the fact that both schemes were established under the same conceptual foundation of new regionalism. It is interesting to note that the advantages of integration as reflected in the orientation paper on the establishment of UEMOA are outlined the same way they were in the instruments establishing ECOWAS. Some of the main advantages sought by both integration schemes are as follows:

- the realization of economies of scale

- the emergence of community enterprises

- improved circulation of goods, services and persons

- increased collective influence of the integrated market in world affairs For Asante (1997:118), it is obvious that all these advantages are much easier to realize within the broader ECOWAS market than within UEMOA narrower zone. Although UEMOA possesses a common currency, this alone is not a sufficient guarantee of rapid economic growth and development. A coordination of macroeconomic policies is also necessary for economic growth to happen through regional 
integration. UEMOA countries have not gone far in the coordination of their macroeconomic policies in other sectors outside the monetary area. Furthermore, UEMOA's over-dependence on France would foil the sub-regional efforts to develop productive structures on the basis of collective self-reliance pursued by ECOWAS. On a more political front, Asante (1997:120) notes, UEMOA continued existence poses a challenge to ECOWAS' decision contained in its Revised Treaty to reaffirm its sole legitimacy as an integrating force in West Africa.

Asante predicts that as the two schemes reach an advanced stage in their respective developments, their incompatibility will be a source of conflict. In the current conditions, it is envisaged that UEMOA will mature into a full customs union before ECOWAS. The more advanced stage of UEMOA's trade liberalization scheme could pose problems for ECOWAS. This means that there is the potential for a conflict of loyalty between the two sub-regional schemes.

In many cases, as Aly (1994:145) notes, member countries find it difficult to reconcile the contradictory provisions of both treaties. As a result, they simply prioritize. In this view, it is unclear whether Francophone states would still remain loyal to ECOWAS after their international trade and economic development interests have been geared toward by UEMOA (Asante, 1997:127).

Another seemingly important contradiction has been noted. Under the ECOWAS scheme, the rights and obligations of members deriving from previously signed contracts (including those of CEAO later transferred to UEMOA) are not affected. On the other hand, all ECOWAS members(without exception) are obliged to remove all provisions (discriminations) from prior treaties that are not compatible 
with the provisions of the ECOWAS Treaty. In addition, members should not enact new provisions that contradict the Treaty (Aly, 1994:161).

This means that the ECOWAS Treaty technically prohibits the creation of UEMOA, which came into existence after the formation of ECOWAS. Even more important is the fact that, according to the ECOWAS Treaty, UEMOA members (all of whom are signatories of the Treaty) would be obligated to extend all preferences granted to each other to all of the members of ECOWAS. In other words, UEMOA has to cease existing in order to merge with ECOWAS at some point of time. This has not been the case yet, however, because UEMOA members have persistently requested a derogation from ECOWAS' Article 20 which requires that "Members states shall accord one another in relation to trade between them, the most favored nation treatment" (Asante, 1986:165). It is the granting of this derogation which has maintained the "legality" of Francophone integration schemes from CEAO to UEMOA, despite the obvious contradiction with the ECOWAS Treaty. Another problem related to the existence of overlapping integration schemes in West Africa is, as Aly (1994:151) puts it, the problem of unnecessarily rising costs of regional cooperation in terms of human and financial resources. In short, Aly finds that there are simply too many intergovernmental organizations in West Africa, since after the independence more than fifty IGOs have in fact been established. ECOWAS has to compete not only with UEMOA, but also with all other West African intergovernmental organizations.

UEMOA is exactly the most comprehensive of these IGOs which competes with ECOWAS in terms of resources. It is does not always come as a surprise that 
the failure of some ECOWAS' member states to meet their financial obligations has been such a long- standing problem (Bach, 1999:181). Some UEMOA countries (e.g., Niger, Mali, Benin) have simply not honored their contribution to ECOWAS for several successive years. The gravity of this problem has prompted the ECOWAS Secretariat to introduce the Community Tax on goods from third countries in order to reduce the organization's financial dependence on member contributions (ECOWAS, 2000).

For some other analysts, including Bach and Aly, Francophone regionalism constitutes an impediment to West African integration because of the pervasive link that still exists between Francophone states and France. They argue that the special relationship between French-speaking West African countries and their former colonizer has severely limited the extent of regional cooperation in West Africa. France's influence over Francophone African states is recognized to be much higher than that of any other former colonizer in Africa (Aly, 1994: 68). As Francophone integration schemes have all been created under France's aegis, the institutions of Francophone regionalism are thus perceived to be incompatible with ECOWAS' goal of "collective self-reliance". The trade patterns of Francophone countries seem to indicate a continued dependence on France which goes well beyond the dependence of most Anglophone countries vis-à-vis Great Britain.

France's strong economic presence is also reinforced by the existence of the CFA Franc. The fact that Francophone countries have a currency which is linked to the French Franc gives an advantage to French companies over those of any other countries outside the Franc zone. As a result, trade between France and Cote d'Ivoire 
is much easier than trade between Côte d'Ivoire and Nigeria, for instance. Hence, Francophone regionalism is simply dismissed as a neo-colonial scheme aimed at maintaining France's domination in the region. For this reason, some of ECOWAS' shortcomings have been attributed to the continued existence of Francophone regionalism in the area (Aly, 1994:90). The next section examines these alleged shortcomings of ECOWAS. In this analysis, I will argue that Francophone states are not solely responsible for the alleged failures of ECOWAS.

\section{ECOWAS' SHORCOMINGS.}

In spite of ECOWAS' recent achievements (as described in the previous chapter), ECOWAS has encountered numerous problems in the pasts. According to some, the problems encountered by ECOWAS are wide-ranging. Problems like the slow pace of ratification of Community conventions and protocols, the low rate of implementation of Community acts and decisions, delays in reacting to request for information from member states, poor attendance at meetings, and excessive delays in payment of contributions are often cited (Bundu, 1997:36-37). Looking at these issues, Bach (1990: 61) has noted that it is too easy to hold Francophone states as solely responsible for some of ECOWAS' disappointments.

If it is true that Francophone and Anglophone states are equally responsible for ECOWAS' achievements, they also ought to share collectively the blame for some of its failures. In fact, I argue that there is no single area where Francophone states are more responsible than Anglophone states for the shortcomings of 
ECOWAS. For instance, on the issue of membership dues, Anglophone states do not have better payment records than Francophone states. Liberia and Sierra Leone have some of the worst payment records over the last decade and a half. On the other hand, Côte d'Ivoire stands out with Nigeria as the only state with perfect payment records (Panafrican News Agency, 2000).

Clearly, irregularities or lack of payment on the part of some Francophone states cannot be interpreted only as a lack of commitment from French-speaking countries. For almost two decades after its creation, ECOWAS was characterized by a lack of implementation of its decisions and by the inability to meet its own objectives. In this domain Anglophone states have shown no greater community spirit than the Francophone countries (Bundu, 1997:44).

Some of ECOWAS' problems simply derive from its basic structural weaknesses. An important weakness of the scheme is the absence of autonomy in the secretariat decision-making process. All issues have to be referred to the annual conference of head of states. It is crucial to note that ECOWAS has historically suffered from poor language communication due to its use of three official languages: French, English and Portuguese. Very few ECOWAS' officials are actually bilingual, and there has been a constant need to call on costly external translation services. In short, bureaucratic hurdles have hindered the smooth functioning of ECOWAS' operations (Bach, 1990:61).

Another important structural problem that ECOWAS has faced since its creation is the low level of intra-regional trade. ECOWAS' creation has not resulted in any significant increase in intra-regional trade. Intra-regional trade in West Africa 
as a percentage of total external trade is still among the smallest compared to other regions in the world with integration schemes (Gambari, 1991:39). Multiple monetary zones and low level of monetary cooperation have not permitted any substantial progress in this matter.

Although intra-West African trade was only estimated at 4 per cent in 1997, this number was even boosted by the fact that intra-regional trade among UEMOA countries was over 10 per cent, the highest number for any regional sub-grouping on the continent (Panafrican News Agency, 2000). While Franc intra-zone trade within ECOWAS increased regularly during the decade of the 1980's, intra-Anglophone countries trade within ECOWAS was cut in half. Over the same period of time trade between Francophone and Anglophone ECOWAS countries stagnated (Gamabari, 1991: 39).

This point shows that the low level of Franco-Anglophone trade is not the only cause for the relatively small quantity of intra-regional trade in West Africa. The fact that intra-Anglophone trade within ECOWAS was lower than both intraFrancophone trade and Francophone-Anglophone trade is a clear illustration of the actual source of the problem. The existence of the Franc zone should not be used so readily as an explanation for ECOWAS' early bad performance in the domain of trade liberalization. If Francophone states had any impact at all in this domain, it was clearly a positive one since their efforts helped to raise the overall percentage of sub-regional trade.

In fact, the low level of intra-regional trade in West Africa is mostly due to ECOWAS' inability to make any substantial progress in the area of trade 
liberalization. ECOWAS' early trade liberalization schemes, as most of its other early projects, simply lacked depth. ECOWAS has had to postpone several times its trade liberalization projects to emphasize instead the issue of institution-building. This process of institution-building involved the adoption of common regulations, the harmonization of custom nomenclature, and the establishment of common terms for road transports. Although a lot of time was devoted to this institution-building process, trade liberalization continued to stall afterwards. A major reason for this stalling of ECOWAS liberalization scheme is also due to disagreements on the "rule of origin" provision of the treaty (Ojo,1999:122).

The "rule of origin" provision was intended to ensure preferential treatment for products from businesses owned by West Africans. However, the Anglophone states of Ghana and Nigeria, which had naturalized major foreign-owned corporations pushed for a set of exclusion criteria which ultimately led to some problems. Nigeria and Ghana wanted to undermine French-owned firms which dominated Francophone countries such as Cote d'Ivoire and Senegal (Ojo, 1999:122). The two leading Anglophone states' insistence to exclude foreign-owned firms, which actually produce most of the region's primary goods, was is in effect what kept the level of intra-regional trade in West Africa low. Hence, as surprising as it may sound, some Anglophone states (the most important ones) prevented ECOWAS from making progress on a issue central to its treaty.

As previously noted, a recurrent criticism against UEMOA and Francophone West African countries in general has been the fact that UEMOA countries have preserved strong links with France. These links are seen by 
Anglophone states as a main impediment to West Africa's integration. Based on this fear of France's influence in the region, ECOWAS is sometimes presented as the only alternative for truly getting the region out of colonialism.

But, a close analysis of Anglophone states' exchange patterns reveals a different story. As Asante (1999:135) notes, unlike the French, the British have not chosen a continued direct involvement in their former colonies. Instead, the British have encouraged efforts by Multinational Corporations (MNCs) to invest in the region. Resources are extracted by MNCs and often benefit Great Britain. This continued advantage for Great Britain takes place, however, without the more overt use of direct power over the internal affairs of the former colonies. As a result, the former British colonies only give the appearance of having greater control over their destiny than the former French colonies.

The illusion of self-reliance is quickly dispelled when one look at figures which reveal dependence of both Francophone and Anglophone states in West Africa is roughly equal. As an illustration, French monopolies control 87.4 per cent of Senegal's economy and about 80 per cent of Côte d'Ivoire's economy. But similarly, British monopolies control 87 per cent of Gambia's economy and 84.4 per cent of Sierra Leone's own. In Nigeria, the so called "West African giant", foreign monopolies still control 65 per cent of industrial investments. In Ghana, foreign monopolies also control 76 per cent of all industrial investments (U.S. Treasury, 2000).

Francophone integration schemes cannot be seen as the unique reason for dependency of the sub-region as Anglophones states suffer from the same level of 
infiltration from Great Britain even without the presence of pervasive political links with their former metropole. Suggesting that UEMOA should be disbanded in order to reduce the overall dependency of West Africa is simply a misinterpretation. With or without UEMOA, the destiny of all ECOWAS countries is still shaped in large measure by outside forces, including the former metropoles. At least, UEMOA provides Francophone states with a forum where problems are collectively resolved. Francophone states have perhaps done a better job at getting the most from their neo-imperialistic context. If Francophone states cannot be held solely responsible for ECOWAS' drawbacks and lack of initial progress, one may also wonder if they can at all contribute to ECOWAS.

\section{UEMOA AS A COMPLEMENT TO ECOWAS.}

To the question of whether UEMOA constitutes an obstacle to West Africa's integration on the basis of ECOWAS' model, Emeka and others have suggested that it does not (Emeka, 1986:34). In Emeka's view, UEMOA does not represent an impediment to ECOWAS because, indeed, ECOWAS has its own shortcomings. On the contrary, he argues, UEMOA has distinct benefits which can be used by ECOWAS

First, as was noted in the first chapter one, UEMOA countries have a long history of cooperation which dates from French colonialism. Because of this long history of cooperation, Francophone states have developed a greater sense of solidarity. This solidarity has facilitated the implementation and the deepening of 
their own integration scheme (Asante, 1986:163). The fact that the Francophone states that are part of UEMOA are all core founding members of ECOWAS represents an advantage. UEMOA's states bring with them into ECOWAS their experience of regional cooperation.

Many scholars of regional integration have stressed the importance of the emergence of one country, or one group of countries, as "the prime mover of integration efforts". Abengwu, for instance, underlines that "there must emerge a dynamic center of gravity within the prospective integrating area". In West Africa, it can be said that UEMOA member states represents such a dynamic center of gravity necessary to West Africa's integration (Abengwu, 1975:131).

UEMOA can serve as a "prime mover" for West Africa's integration in those areas where its scheme has achieved more substantial depth. Monetary integration is the key area where UEMOA's depth has been noted. Since the adoption of its Revised Treaty, ECOWAS has also made the creation of a single currency one of its primary objectives. The fact that eight out of fifteen West African countries already share a common currency is a distinct asset. In fact, ECOWAS admits that in order to accomplish monetary integration the CFA Franc (which is shared by all UEMOA countries) must be taken into account (ECOWAS, 2000).

Because the CFA Franc already exist as a viable monetary unit, ECOWAS does not have to work to harmonize monetary policies between fifteen different currencies and fifteen different central banks. Instead, all ECOWAS has to do is to find harmonization between only nine currencies and nine central banks. Since 
ECOWAS plans to create a second monetary zone that would be parallel to the CFA zone as a first step toward instituting a single currency, the CFA Franc certainly could serve as a reference and model for that second currency. Furthermore, countries of the second monetary zone could learn a lot from the experience of UEMOA.

Similarly, the BCEAO (the Central Bank of UEMOA countries) could also prove very useful to ECOWAS when it comes to establishing a new regional Central Bank. BCEAO's headquarters in Dakar are already well organized with a very professional staff. The BCEAO could even become the prime location for the new ECOWAS central bank. This would reduce the cost of constructing a new Bank headquarters in a different city. Furthermore, BCEAO's long experience in dealing with common monetary policies would be essential to ECOWAS.

Because the institutions of UEMOA have already earned a large degree of credibility due to their sound monetary policies, an extension of these institutions to ECOWAS or even a duplication of the same mechanisms in a larger regional setting would without a doubt prove successful. Of course, the new monetary institutions would still have to gain supranationality, as is currently the case with UEMOA's institutions. Finally, the existence of a link between the CFA Franc and the Euro (through the French Franc) would facilitate the direct pegging of the extended CFA Franc to the Euro and other international currencies.

Thus, ECOWAS will have in effect two main alternatives in order to establish its monetary union. The first alternative will be an extension of the CFA Franc and its zone. The second alternative will be the creation of another monetary 
zone which exactly replicates the CFA Franc model and would still be linked to the European currency. A fusion of the two monetary zones is the best bet for the realization of a single regional currency. Whichever of these two options is followed, the existence of the CFA Franc constitutes a distinct advantage.

Additionally, as Cobham (1997) and Robinson (1997) have noted, a West African Monetary Union which would adopt a direct peg with the Euro could also reserve itself the right to change the parity between its currency and the Euro in exceptional circumstances. In short, they both agree that pegging to the Euro would not represent a subordination of West Africa's monetary policies to European decision-making. Rather, it would represent a method chosen by West African countries to attain their own monetary policy objectives. The second wave of regionalism in which West African integration efforts are currently taking place goes in this direction. It is ideologically more outward looking and no longer rejects links with developed countries, even in monetary domains. As Bach (1999:19) has noted, in the second wave of regionalism developing countries are not seeking to reduce North-South relations as a way to increase South-South cooperation. What they seek instead is an increased partnership with developed countries on multiple grounds. Hence, the pegging of a new West African currency to the Euro could clearly take place within the context of such a new partnership.

All members of ECOWAS have the same goal. But Francophone states have simply moved faster toward those objectives than Anglophone states. UEMOA and ECOWAS do not differ fundamentally in terms of their integration objectives. They differ more in terms of the way they seek to implement these objectives. While 
ECOWAS has broadened the scope of its activities to achieve some community objectives, UEMOA has gone deeper in the implementation of specific objectives by concentrating mostly on monetary integration.

One can thus imagine that UEMOA could move even further towards more intense economic integration, while still complying with ECOWAS' agreements which are not contradictory after all. When UEMOA was established in 1994, it clearly set its goals and objectives within the parameters of ECOWAS' policies. In a sense, anything achieved by UEMOA is also part of an objective sought by ECOWAS. One may thus agree with Kennes who contends that UEMOA may indeed become a positive stimulus for integration at the ECOWAS level. Kennes concludes: "if an integration agenda cannot be implemented at the level of UEMOA members which share a common currency, and part of their recent history, then it is simply unlikely that it can be put to work in the much wider context of ECOWAS" (1999:33).

\section{CONCLUSION}

UEMOA's existence constitutes a definite advantage for the integration efforts pursued at a larger regional level. As I have demonstrated in this chapter, some of the shortcomings and drawbacks of ECOWAS are not totally imputable to UEMOA states. As a group, Francophone states do not have more responsibility for ECOWAS' alleged poor performances than do the Anglophone states. On the 
contrary, as a group, Francophone states can make a very substantial contribution to ECOWAS.

UEMOA and ECOWAS (since the Revised Treaty) are integration schemes which follow the new wave model of regionalism. As such, they share many general characteristics. Some analysts find UEMOA and ECOWAS redundant, but it is because both schemes essentially seek to accomplish similar objectives. Monetary integration, trade liberalization, realization of economies of scale, improved circulation of goods, of service, and of people, constitute some of the most important common goals sought by the two organizations. But more than sharing similar goals, the main point I want to emphasize is that UEMOA and ECOWAS are indeed complementary endeavors. UEMOA possesses attributes desirable for ECOWAS, and vice versa.

UEMOA has been a successful monetary integration, as noted in the first chapter. But UEMOA has not really achieved more than that. Its monetary integration has worked well, but other domains of integration have sometimes been neglected. UEMOA was not able to significantly broaden the scope of its integration. On the other hand, and despite its lack of monetary integration, ECOWAS has implemented integration projects in a wide array of sectors (as discussed in chapter 2). ECOWAS has been more successful at expanding the regional integration experience to domains that UEMOA could not imagine to develop. Both schemes are multidimensional in their objectives. But ECOWAS has been more multidimensional in the implementation of its objectives. ECOWAS' more recent achievements have clearly demonstrated this phenomenon. As Bjorn 
Hettne's (1995:13) definition of the second wave of regional integration reminds us, this current wave is a multidimensional process that includes economic, political, social, and cultural aspects. In West Africa, ECOWAS sought to develop integration in all these sectors and many others. But, to succeed in this task, ECOWAS will need the long experience of UEMOA in the area of monetary integration. The successful model of European integration has shown that both depth and scope are required if regional cooperation efforts are to last and yield benefits to their participants. The collaboration between ECOWAS and UEMOA is not just an option. It is an imperative choice for West Africa's overall integration. In my view, it will also be the fastest way to achieve it. 


\section{GENERAL CONCLUSION}

This research has shown that west Africa must fully embrace regional integration. The creation of bigger and powerful economic blocs among developed countries makes regional integration an even more pressing issue for West African nations than it was in the past. Fortunately, West African states have chosen to follow the second wave of regionalism. The question is no longer whether West African nations really want to integrate, as was often asked during the first round of regionalism. Now, the question is rather what is the best way for West African nations to integrate? In response to this question, some scholars have suggested the elimination of UEMOA to consolidate ECOWAS as the preferred strategy. In this research, I have refuted this argument by arguing to the contrary that UEMOA has the potential to reinforce ECOWAS and can thus benefit the integration process of West Africa.

In the first chapter, I reviewed the history of French-speaking regionalism from the first wave of integration to the second. I explained how UEMOA came into existence as a product of a long history of cooperation between the Francophone countries of the sub-region. This point has been important to understand the culture of integration that Francophone states have developed and brought with them into ECOWAS. A solid integration culture among member states is deemed to be a very important factor for the success of any integration scheme. The Francophone states of West Africa have a long history of cooperation that goes back to French colonialism. After independence, Francophone West African countries' integration 
schemes started as a result of intra-Francophone rivalries. These early Francophone schemes were more politically driven than economically motivated.

With the creation of the CEAO, Francophone regionalism evolved into a form of economic integration aimed at countering Nigeria's regional hegemonic tendency. Since then, Francophone regionalism has been interpreted to be hostile to any larger integration scheme. In the second wave of integration, the CEAO was dissolved and transformed into UEMOA. The creation of UEMOA represented a change of orientation for Francophone regionalism. This important change has not yet been fully understood by many analysts. Unlike previous Francophone schemes, UEMOA resolutely put itself within the larger framework of West African regional integration. In fact, unlike previous Francophone schemes, UEMOA recognizes ECOWAS' legitimacy as ultimately the sole integration scheme in all of West Africa. Those analysts who still perceive Francophone regionalism as an impediment to West Africa's integration have failed to measure the difference in substance and approach between the "old" Francophone regionalism represented by CEAO and the "new" version represented by UEMOA. These differences are also illustrative of a broad distinction between first wave and second wave integration schemes in general. The first chapter clearly showed what UEMOA's main asset was: the depth of its integration. UEMOA's depth of integration is illustrated by its sophisticated monetary and financial arrangements. It is this depth that constitutes UEMOA's major contribution to West African integration and can thus complement ECOWAS. 
The second chapter presented the crucial motivations that led to the establishment of ECOWAS as the only fully formed regional integration scheme in West Africa. I showed how ECOWAS came into existence out of a desire of both Francophone and Anglophone states to achieve a common objective. This common objective was to bring the sub-region out of its traditional external dependency through the idea of "collective self-reliance". For many analysts, the mere creation of ECOWAS constitutes an achievement since the very diverse colonial heritage of the sub-region had made such an initiative impossible to achieve in the past. A review of ECOWAS' achievements also revealed that they have been the result of joint efforts from both Francophone and Anglophone states. This analysis thus dispelled the view that Francophone states do not contribute to West Africa's integration. As the research has shown, ECOWAS' main advantage is the broad scope of its integration. The scope of ECOWAS' integration has only been possible because of the participation of Francophone states in all the sectors of cooperation.

Further illustrating the equal participation of Francophone and Anglophone States in regional integration initiatives, the third chapter demonstrated that the responsibility for some of ECOWAS' failures is equally shared by Francophone and Anglophone states. This chapter established the potential for UEMOA to serve as a stimulus for sub-regional integration in West Africa within ECOWAS. Since creating a monetary union is a central strategy in ECOWAS' fast track approach to regional integration based on its Revised Treaty, UEMOA's current monetary arrangement was revealed to be very advantageous. The existence of the CFA Franc 
and its link to the Euro can facilitate the entire process of monetary integration within ECOWAS.

The fact that Guinea Bissau and Equatorial Guinea, both of which are non French-speaking countries, have joined the CFA zone and its affiliated institutions seems to confirm the argument that French-speaking regionalism does not constitute an inherent obstacle to regional cooperation and integration in the subregion. This also means that other nations in the region do not even appear to perceive linguistic identity as an insurmountable factor for integration . In fact, it appears that linguistic identity is not even a determining factor for association among the Franc zone countries in West Africa. Guinea has never joined any institution of Francophone regionalism since its independence, while Mauritania withdrew from the Franc Zone in the 1970s.

What thus appears as the most distinctive common characteristic of countries that founded UEMOA is the fact that they have all historically maintained very close links with France. The close neo-colonial ties is also an important factor behind the formation of Francophone regionalism, even though it is not the most important factor. French-speaking Central Africa has the same neocolonial ties, but has not been so successful in its integration. The fact that Francophone West African countries will continue to speak French will have no impact on their relations with their non-Francophone neighbors. But Francophone countries' relations with France may, however, change in the future. This will have an impact on UEMOA's countries connections with their neighbors. 
Further research could analyze more closely Franco-African relations in order to identify more factors that may be favorable to West African integration. As noted in the historical analysis of Francophone regionalism, France's influence over Francophone states has sometimes been a hindrance to the process of subregional integration. But the gradual decline in France's influence over Francophone West African states could offer additional clues as to the potential for UEMOA to serve as a complement to ECOWAS.

As was the case with the formation of the APC Group ${ }^{12}$, for example, the consolidation of the European Union could have a positive effect on the process of regional integration in West Africa. As Chris Alden (1996:24) notes, there is a gradual "Europeanization" of French policy towards Africa. French policy towards Africa is becoming less "French" and more "European." This certainly represents a shift from bilateralism to multilateralism. This shift toward multilaterism also corresponds to the kind of relations developing countries generally seek in the new regionalist era. In West Africa, the intensification of multilateral relations with the European Union could benefit the process of regional integration. A reinforcement of the existing links between UEMOA and the European Union could benefit ECOWAS when it decides to merge its institutions with UEMOA. The absorption of the French Franc into the Euro will create a direct link between the CFA Franc and the European currency. This will be an advantage for ECOWAS if it uses the CFA Franc as the basis for its monetary integration.

${ }_{12}$ The APC refers to the group of African, Caribbean and Pacific countries which came together to negotiate the Lomé Convention with the E.E.C. 
Despite the slow start of ECOWAS, and its disappointing performance during the first wave of integration, commitment to regional integration has been strong since the beginning of the new regionalism in the 1990s. The specter of economic integration has kept the enthusiasm high among ECOWAS countries (Gambari, 1991:56). Since the adoption of ECOWAS' Revised Treaty, Francophone and Anglophone countries have demonstrated a great willingness to work together. In fact, ECOWAS has even achieved more since the 1990s than would have been thought possible only two decades ago (Asante, 1997:167). The wide range of sectors (infrastructure development, transportation, telecommunication, energy, private sectors development, and regional security) affected by the integration scheme is a clear measure of what has been achieved.

In light of this, one cannot perceive how UEMOA's countries could still be seen as an obstacle to West African integration. Undoubtedly, the future success of West Africa's integration will still depend on the ability of the sub-region's two regional organizations to work together. Only the combination of UEMOA's depth and ECOWAS' scope can make West Africa's integration a successful endeavor . Attempting to achieve integration in any other way would certainly be longer and more arduous.

This research had two principal aims:

* To document West African integration efforts through the separate experience of UEMOA and ECOWAS in the larger conceptual contexts of old and new regionalist theories. 
* To evaluate the prospect of full scale integration in West Africa given the current co-existence of the two organizations.

In achieving its aims this research demonstrated that:

1) West African integration can work in the current context of the new regionalism.

2) West African integration can work with both ECOWAS and UEMOA as integral parts of the scheme.

3) UEMOA can reinforce ECOWAS.

4) The existing ties among Francophone countries can facilitate the larger process of integration and do not constitute an impediment to the achievement of common objectives.

The complementarity of ECOWAS' scope and UEMOA's depth is supported by additional conceptual tools. Walter Kennes' concept of "variable speed and geometry" of integration is one such a tool. Kennes' "variable speed and geometry" model is also applicable to the situation of West Africa. For Kennes, the notion of "variable geometry and variable speed" demonstrates that the existence of smaller sub-groupings within larger ones can help consolidate the overall integration process (1999:32-33). Under variable speed, a set of common objectives is agreed upon, but some member states simply agree to move more quickly toward implementation. This model implies that the pace of integration is determined by the fastest members rather than the slowest ones. This model has been quite successful in the European context, where Great Britain's slower pace has not prevented France and Germany to go on with more intensified integration. Based on 
such an approach, some members move ahead towards common policy while others join later. Under variable geometry, a sub-group of member states moves toward deeper integration on a more or less permanent basis (Kennes, 1999:33).

In West Africa, all members of ECOWAS have the same goal. But UEMOA countries have moved faster and deeper towards the accomplishment of those objectives. As was seen in the analysis of the two organizations, UEMOA and ECOWAS do not differ fundamentally in terms of their objectives. They have mostly differed in the way they have decided to prioritize these objectives. While ECOWAS has broadened the scope of its activities to achieve multiple community objectives, UEMOA has gone further and with more intensity in the implementation of crucial objectives such as monetary integration.

The fact that the "variable speed and geometry" theory of integration corroborates the idea of complementarity between UEMOA and ECOWAS is another indication that the analytical conclusions of this research are solid. This point also implies that the study of West African integration can make an important contribution to the general literature on regionalism. What this study has shown is that integration in the context of the new regionalist movement follows a dynamic which is quite different from classical models of integration. For West Africa, the new regionalist scheme has presented actual opportunities for achieving regional integration that other models could not have offered. In particular, the multidimensional aspect of the new regionalism is what has made West African integration possible. 
In West Africa, the salience of non-economic problems (such as security issues) would mean that any attempt of integration strictly limited to economic cooperation would fail. During the first round of integration (which focused mainly on economic cooperation), no substantial progress was made to integrate the subregion. Clearly, the success of economic integration in West Africa will depend on how successful regional organizations are at tackling non-economic issues. Through economic integration, countries seek to achieve economic growth, which is seen as the key to development. But without peace and stability, there could be no economic growth, and thus no development. In the first wave of integration, the link between political stability and economic growth was never really taken in account.

Fortunately for West Africa, the new regionalist approach insists on making this crucial link. The two regional organizations are aware of this necessary foundation. Following this multidimensional path, ECOWAS will keep broadening the scope of its activities while UEMOA will further deepen its economic and monetary union. In a sense, UEMOA and ECOWAS have opted for a division of labor which can only benefit the integration process in West Africa. If West Africa continues on this successful path, ECOWAS and UEMOA could provide a new model of regional integration for other developing countries in the world. 


\section{BIBLIOGRAPHY}

Agbohou, Nicolas. Le Franc CFA et L'Euro contre l'Afrique. Paris: Editions Solidarités Mondiales A.S., 1999.

Aldrich, Robert and John Cornell. France in World Politics. London, Roudlege, 1989.

Anderggen, Anton. France's Relationship with Subsaharan Africa. Westport, Connecticut: Praeger, 1994.

Anglarill, Milda Beatriz. Africa: Teorias y Praticas de la Cooperacion Economica. Buenos Aires, Argentina: Editorial del Belgrano, 1990.

Aly, Ahmad A.H. Economic Cooperation in Africa: In Search of Direction. Boulder, Colorado: Lynne Rennier Publishers, 1994.

Asante, S.K.B. The Political Economy of Regionalism in Africa: A Decade of The Economic Community of West African States (ECOWAS). New York: Praeger, 1986.

Asante, S.K.B. Regionalism and Africa's Development: Expectations, Development, and Challenges. London: Macmillan Press Ltd, 1997.

Bach, Daniel. Regionalization in Africa: Integration and Disintegration. Bloomington: Indiana University Press, 1999.

Betts, Raymonds F. Decolonization: Making of Contemporary World: NewYork: Roudlege, 1998.

Clark, John and David Gardinier. Political Reforms in Francophone Africa. Boulder, Colorado: Westview Press, 1997.

Clolinj, Geerjt Jan. Regional Integration; Benelux and its spillover effects On the European Community. Oxford: Westview Press, 1978.

Deng, A. Lual. Rethinking African Development: Toward a Framework for Social Integration and Ecological Harmony. Trenton, New Jersey: African World Press 1997.

Diagne, Pathé. Pour L'Unité Africaine: Micro-Etats et Integrations Economiques. Paris: Editions Anthropos, 1972.

Diouf, Mockhtar. Integration Economique: Perspectives Africaines. Dakar: Nouvelles Editions Africaines, 1977. 
Emeka, Okolo. West African Regional Cooperation and Development. Oxford: Westview Press, 1990.

Ezenwe, Uka. ECOWAS and the Economic Integration of West Africa. New York: St. Martin's Press, 1983.

Fawcett, Louise and Andrew Hurell. Regionalism in World Politics: Regional Organizations and International Order. New York: Oxford University Press, 1997.

Gambari, Ibrahim. Political and Comparative Dimension of West African Integration: The Case of ECOWAS. Trenton, New Jersey: Humanity Press Publication, 1991.

Gruhn, Isebill. Regionalism Reconsidered: The Economic Commission for Africa. Boulder: Westview Press, 1979.

Harshé, Rajen. Pervasive Entente: France and Ivory Coast in African Affairs. Atlantic Highlands, NJ: Humanity Press, 1984.

Hass, Ernst. The Obsolescence of Regional Integration Theory. Berkeley, California: Institute of International Studies, 1975.

Institut Universitaire Européene. Atelier sur la Promotion de la Cooperation et L'Integration en Afrique Sub-saharienne, 1992.

Johnson, Wesley. Double Impact: France and Africa in the Age of Imperialism. Westport, Connecticut: Greenwood Press, 1985.

Kouadio, François. Les Politiques d'Integrations en Afrique. Abidjan: Mgi, 1996

Kouamé, Patrice. Integration Monétaire et Croissance Economique en Afrique de l'Ouest. Abidjan: Les Nouvelles Editions Africaines, 1988.

Kirkwood, Kenneth. Britain and Africa. Baltimore: The John Hopskins Press 1965.

Lavergne, Réal. Regional Cooperation in West Africa: A Multidimensional Perspective. Trenton, New Jersey: Humanity Press Publication, 1991.

Lateef, Noel. Crisis in the Sahel. A Case Study in Development Cooperation. Boulder, Colorado: Westview Press, 1990.

Onwuka, I. Ralph and Timothy M. Shaw. Africa in World Politics: into the 1990s. New York: St. Martin Press, 1989. 
Ouattara, Bouraima.Economic Cooperation Among Developing Nations. Editions Plomb, 1999.

Oyejide, Ademola \& Ibrahim Elbadawi, Paul Collier. Regional Integration and Trade liberalization in Subsaharan Africa. London, Macmillan Press, 1997.

Martin, Guy. The Historical, Economic and Political Bases of France's Africa Policy. Paris: Editions Plomb, 1991.

Mazrui, Ali. The Anglo-African Commonwealth: Political Friction and Cultural Fusion. London, Pergamon Press, 1977.

Mendhoza, Miguel. Trade Rules in the Making: Challenges in Regional and Multilateral Negotiations. Standford, California: Standford University Press, 1999.

Nishijima, Shoji. Cooperation or Rivalry? Regional Integration in the Americas and Pacific Rim. Boulder, Colorado: Lynne Riennier, 1996.

Riley, Raymond Charles. Benelux: An Economic Geography of Belgium, The Netherlands, and Luxembourg. New York: Holmes and Meier Publishers, 1975.

Robinson, Kenneth E. Constitutional Reforms in French Tropical Africa. London, Pergamon Press, 1988

Seidman, Frederick.Twenty First Century Africa: Toward New Vision For Self Sustainable Development. Trenton, New Jersey: Africa World Press, 1992.

Thomas, Kenneth P. and Mary Ann Tetrault. Racing to Regionalize: Democracy, Capitalism, and Regional Political Economy. Boulder, Boulder, Colorado: Lynne Rienner,_1992.

\section{Articles and Book Chapters}

Asante, S.K.B. "ECOWAS: Towards Autonomy or Neocolonialism." In Africa in World Politics: into the 1990s". New York: St. Martin Press, 1989.

Agbohou, Nicolas. “Le Franc CFA et L'Euro contre l'Afrique”. Notre Voie: (600), May 10, 2000.

Anyang', Nyong'O. "Regional Integration in Africa: Unfinished Agenda." Nairobi: African Academy, 1990. 
Bach, Daniel. "Francophone Regional Organization and ECOWAS. In West African Regional Cooperation and Development. Oxford Westview Press, 1990.

Ben-Yamed, Bechir. "Ce que je Crois: La France Lâche l'Afrique." Jeune Afrique, March 27, 2001.

BCEAO: “L’Union Monétaire Ouest Africaine.” Rapport sur l'Integration. 2000

Bundu, Abass. "ECOWAS and the Future of Regional Integration in Africa." In Regional Cooperation in West Africa: A Multidimensional Perspective.

Trenton, New Jersey: Humanity Press Publication, 1991.

Carboo, Desmond. "ECOWAS: Are we Ready for a Unified Monetary Zone." Panafrican News Agency, May 19, 2000.

Collins, C.D.C. "History and Institutions of the EEC." In The Economics of European Community. Oxford: Philip Allan, 1987.

ECOWAS. "The Treaty." www.cedeao.org

ECOBANK. www.ecobank.com

Fine, Jeffrey and Stepphen Yeo. "Regional Integration in sub-saharan African.".In Regional Integration and Trade liberalization in Subsaharan Africa. London, Macmillan Press, 1997.

Hugon, P. "Zones Monetaires et Integrations Regionales: Le cas de la zone CFA." Techniques Financieres et Development. Paris, 1990.

Obeng. A.V. "Regional and Sub-Regional Cooperation in Africa: A development Perspective." Conference on West Africa's Integration. Dakar , January 1993.

OECD. "International Economic Integration among Developing Nations." Paris: OECD, Development Division, 1987.

OECD. "Statistique sur le Development International". Paris: OECD, Development Division, 2000.

Ojo, Olatunde J.B. "Economic Integration: Nigeria and the Formation of ECOWAS". Nigerian Journal of Economic and Social Studies, September 1987.

Kennes, Walter. "African Regional Integration and the European Union." In Regionalization in Africa: Integration and Disintegration. Bloomington: Indiana University Press, 1999. 
Lumumba-Kasonga, Tukumba. "The Rise of Social and Political Movements: A Challenge for Regional Integration or a Factor towards Real Cooperation within ECOWAS." Conference on West Africa's Integration. Dakar, January 1993.

Martin, Guy. "France and Africa." In France in World Politics. London: Roudlege, 1989.

Mendhora, Robinton. "Lessons of UMOA for ECOWAS." Conference on West Africa's

Integration. Dakar, January 1993.

Mendhora, R.obinton. "The West African Monetary Union: Institutional Arrangements and the links with France." Canadian Journal of Development Studies, 12 (2) 151-180. 1992.

Nduba, Echezona. "International Integration in a New World Order." Conference on West Africa's Integration. Dakar, January 1993.

Soudan, François. "La France Lâche l'Afrique.” Jeune Afrique. March 27, 2001.

Sulaima, Mohamed. "ECOWAS: Moving Toward a New Frontier." News Agency. June 5, 2000.

Treasury, U.S. Government. Breakdown of Foreign Capital Companies. www.treasury.gov.tr/english/ybs/ulkeing.htn

Tsa, Goodin. "Three Phased Approach to West Africa Integration." Panafrican News Agency, May 24, 2000.

UNCTAD. "Economic Cooperation in the South." New York: June,1989. 